\title{
The Effect of Unfair Chances and Gender Discrimination on Labor Supply
}

Citation for published version (APA):

Gagnon, N., Bosmans, K., \& Riedl, A. (2020). The Effect of Unfair Chances and Gender Discrimination on Labor Supply. Maastricht University, Graduate School of Business and Economics. GSBE Research Memoranda No. 005 https://doi.org/10.26481/umagsb.20005

Document status and date:

Published: 20/02/2020

DOI:

10.26481/umagsb.20005

Document Version:

Publisher's PDF, also known as Version of record

\section{Please check the document version of this publication:}

- A submitted manuscript is the version of the article upon submission and before peer-review. There can be important differences between the submitted version and the official published version of record.

People interested in the research are advised to contact the author for the final version of the publication, or visit the DOI to the publisher's website.

- The final author version and the galley proof are versions of the publication after peer review.

- The final published version features the final layout of the paper including the volume, issue and page numbers.

Link to publication

\footnotetext{
General rights rights.

- You may freely distribute the URL identifying the publication in the public portal. please follow below link for the End User Agreement:

www.umlib.nl/taverne-license

Take down policy

If you believe that this document breaches copyright please contact us at:

repository@maastrichtuniversity.nl

providing details and we will investigate your claim.
}

Copyright and moral rights for the publications made accessible in the public portal are retained by the authors and/or other copyright owners and it is a condition of accessing publications that users recognise and abide by the legal requirements associated with these

- Users may download and print one copy of any publication from the public portal for the purpose of private study or research.

- You may not further distribute the material or use it for any profit-making activity or commercial gain

If the publication is distributed under the terms of Article $25 \mathrm{fa}$ of the Dutch Copyright Act, indicated by the "Taverne" license above, 
Nickolas Gagnon,

Kristof Bosmans, Arno Riedl

The effect of unfair chances and gender discrimination on labor supply

$\mathrm{RM} / 20 / 005$

\section{GSBE}

Maastricht University School of Business and Economics

Graduate School of Business and Economics

\section{P.O Box 616}

NL- 6200 MD Maastricht

The Netherlands 


\title{
THE EFFECT OF UNFAIR CHANCES AND GENDER DISCRIMINATION ON LABOR SUPPLY*
}

\author{
Nickolas Gagnon
}

\author{
Kristof Bosmans
}

Arno Riedl

January 14,2020

\begin{abstract}
Labor market opportunities and wages may be unfair for various reasons, and how workers respond to different types of unfairness can have major economic consequences. Using an online labor platform, where workers engage in an individual task for a piece-rate wage, we investigate the causal effect of neutral and gender-discriminatory unfair chances on labor supply. We randomize workers into treatments where we control relative pay and chances to receive a low or a high wage. Chances can be fair, unfair based on an unspecified source, or unfair based on gender discrimination. Unequal pay reduces labor supply of low-wage workers, irrespective of whether the low wage is the result of fair or unfair chances. Importantly, the source of unfair chances matters. When a low wage is the result of gender-discriminatory chances, workers matched with a high-wage worker substantially reduce their labor supply compared to the case of equal low wages $(-22 \%)$. This decrease is twice as large as those induced by low wages due to fair chances or unfair chances coming from an unspecified source. In addition, exploratory analysis suggests that in response to unequal pay, low-wage male workers reduce labor supply irrespective of the source of inequality, whereas low-wage female workers reduce labor supply only if unequal pay is due to gender-discriminatory chances. Our results concerning gender discrimination indicate a new reason for the lower labor supply of women, which is a prominent explanation for the gender gap in earnings. (JEL: D90, E24, J22, J31, J71, M5)
\end{abstract}

Keywords: Labor Supply; Wage Inequality; Procedural Fairness; Gender Discrimination

\footnotetext{
${ }^{*}$ We are grateful to audiences at seminars in Berlin, Heidelberg, Lyon, Maastricht, Montréal (CIRANO, HEC, and Concordia), Québec, and Tucson, and at the ASFEE (Toulouse), Conference on Decision Sciences (Konstanz), ESA (Los Angeles), IMEBEES (Utrecht), M-BEPS (Maastricht), HDPD Retreat (Heerlen), and Paris2ZEW Workshop on Market Design (Mannheim) for very useful comments. We are also thankful to Charles Bellemare, Pol Campos i Mercadé, Martin Dufwenberg, Bernard Fortin, Gautam Gowrisankaran, Olivier Marie, Pierre-Carl Michaud, Leticia Micheli, Rebecca Morton, Marcello Negrini, Charles Noussair, Juan Palacios, Noémi Péter, Gerhard Riener, Christina Rott, Arthur Schram, Peter Werner, and Henrik Zaunbrecher, for their valuable comments. Nickolas Gagnon acknowledges financial support from the Fonds de recherche du Québec - Société et culture, and from the Human Decisions \& Policy Design Research Theme of Maastricht University. Authors Information: Department of Microeconomics and Public Economics, School of Business and Economics, Maastricht University, P.O. Box 616, 6200 MD Maastricht, The Netherlands. Nickolas Gagnon (corresponding author): $\mathrm{n}$.gagnon@maastrichtuniversity.nl. Kristof Bosmans: k. bosmans@maastrichtuniversity.nl. Arno Riedl: a.riedl@maastrichtuniversity.nl. We obtained ethical approval from the Ethical Review Committee Inner City of Maastricht University (ID: ERCIC-054-15-11-2017), and pre-registered our hypotheses in the American Economic Association's Randomized Control Trials Registry (ID: AEARCTR-0002655).
} 


\section{Introduction}

Chances are a pervasive feature of labor market activities and outcomes. Workers are confronted with them when they face hiring, bonus payment, promotion, and dismissal decisions. Those chances might be fair, but can also be unfair for many reasons, ranging from favoritism and nepotism to discrimination. For instance, recent work suggests that women evaluated for tenure in economics departments face lower chances than men of equal ability (Sarsons et al., 2019). In this paper, using an experiment, we present the first investigation of the causal impact of unfair chances in receiving a high or low wage on labor supply decisions of workers. Moreover, we provide the first examination of the causal effect of gender discrimination (through gender-discriminatory unfair chances) on labor supply decisions.

Recent work has shown that unequal pay can have major effects on workers' behavior, such as reduced labor supply and productivity as well as increased job separations (Bracha et al., 2015; Breza et al., 2018; Dube et al., 2019). At the same time, a lasting idea in economics is that unfair chances influence equity judgments (e.g., Diamond, 1967), and empirical studies have provided support for this claim (e.g., Bolton et al., 2005; Brock et al., 2013; Cappelen et al., 2013). ${ }^{1}$ Combining the results of those two strands of literature suggests that unequal chances on labor markets may also affect workers' behavior significantly, although this has yet to be studied. Moreover, that inequality comes from a specific source such as gender discrimination may generate especially strong responses. In spite of this, whether gender-discriminatory inequality does provoke reactions that are distinct from more neutral inequality has thus far not been examined.

To investigate the causal effect of unfair chances and gender discrimination on labor supply, we conduct a controlled experiment. We use an online labor platform, where we hire workers who individually engage in a task at a fixed piece-rate wage. We can draw causal conclusions by fully controlling both the chances leading to pay inequality between workers and the source of these chances. Workers first learn the procedure that will determine their wage as well as the wage of another worker, which can be high or low. Then, workers are informed of their own and the other worker's resulting wage, after which they decide individually how much to work.

To cleanly isolate the effect of chances and their source on labor supply, we implement a design that rules out peer interactions, risk, and reciprocity considerations. Providing less labor is costly to workers because it reduces their own earnings, but has no other effects. An important feature of our design is that we implement an explicit gender-discriminatory policy, which has been approved by the local ethical review committee. Moreover, the use of an online

\footnotetext{
${ }^{1}$ Psychologists have suggested that procedures regarded as unfair can engender undesirable work behavior, such as decreased productivity and retaliation (e.g., Leventhal et al. 1980, Skarlicki and Folger 1997).
} 
labor platform provides us with a relatively large number of participants who are arguably more representative than student participants. The anonymity of the online platform also helps in avoiding peer effects from observing other workers quitting the task. ${ }^{2}$

In our experiment we measure labor supply in the real effort task and implement five different payment schemes (treatments) where we create wage inequality through fair or unfair chances and also vary the source of unfair chances. We randomize each worker into one of the five schemes. In each scheme, a worker is anonymously matched with another worker engaged in the same individual task. In two baseline schemes, called EQLOW and EQHIGH, both workers receive the low wage or receive the high wage, respectively. In these schemes, we do not mention the procedure that determines the wages. In the other three schemes workers in a pair receive unequal wages: one receives the high wage and one receives the low wage. In the payment scheme UNEQFAIR, both workers have a fair chance (50\%) of receiving the high wage. By contrast, in the schemes called UNEQUNFAIR and UNEQDISCR one worker has a $25 \%$ chance of receiving the high wage and the other has a $75 \%$ chance. In the former scheme no specific source for the unfair chances is mentioned. In the latter scheme, pairs of workers consist of a man and a woman, and they are informed that their chances depend on their gender. One worker has a $25 \%$ chance of receiving the high wage explicitly because she is woman or he is a man, whereas the other worker has a $75 \%$ chance because he is man or she is a woman.

To derive our hypotheses regarding labor supply in the different schemes, we provide a theoretical framework which extends the framework on inequality aversion and work morale by Card et al. (2012) and Breza et al. (2018) with the model of social preferences incorporating chances by Saito (2013). The model assumes that workers engaged in the same work dislike wage inequality, and more so if this wage inequality is the result of unfair chances. Both unfair chances and wage inequality increase the marginal disutility of working, thus reducing labor supply. In addition, we posit that gender discrimination as the source of unfair chances creates an extra psychological cost that further increases workers' marginal disutility from unequal treatment.

We compare the labor supply of workers at a given wage across payment schemes, and test four pre-registered hypotheses. Our first and second hypothesis states that for both lowwage workers and high-wage workers, unequal wages, unfair chances, and gender discrimination each incrementally decrease labor supply. Our third hypothesis says that these effects are stronger for low-wage workers than for high-wage workers. Finally, our fourth hypothesis conjectures that men and women may not react equally to gender-discriminatory chances compared to the same unfair chances coming from an unspecified source.

\footnotetext{
${ }^{2}$ In Section IV.B we discuss potential drawbacks of online experiments and how we minimize them.
} 
Our main results can be summarized as follows. In line with the first hypothesis, low-wage workers in worker pairs with unequal pay who receive their low wage through fair chances work significantly less $(-13 \%)$ than low-wage workers who are matched with another low-wage worker. This effect of wage inequality is consistent with results reported in the three previous studies on the topic (Bracha et al., 2015; Breza et al., 2018; Dube et al., 2019). Interestingly, the fact that in our case fair chances determine the unequal pay does not remove this negative effect. Further, in contrast to the first hypothesis, low wages resulting from unfair chances based on an unspecified source produce a similar labor supply as low wages based on fair chances. However, low-wage workers do significantly decrease their labor supply if they face unfair gender-discriminatory chances. The average impact of gender discrimination on labor supply is significant and large in economic terms. Low wages resulting from unfair genderdiscriminatory chances reduce labor supply by $15 \%$ relative to low wages coming from unfair chances based on an unspecified source, and by $22 \%$ relative to equal low wages.

In contrast, high-wage workers appear to be immune to the different types of inequality that we employ. In no case is their labor supply significantly different in one payment scheme than in another. Thus, the second hypothesis is not supported.

The third hypothesis, that the adverse effects on labor supply are stronger for low-wage workers than for high-wage workers, holds when comparing the payment scheme with genderdiscriminatory chances to the other schemes. In all other comparisons, low-wage workers and high-wage workers do not significantly differ in their responses.

Finally, we obtain evidence that low-wage women respond more strongly to gender-discriminatory unfair chances than low-wage men do, supporting our fourth hypothesis. Moreover, an exploratory comparison across all five payment schemes reveals a distinct gender difference among low-wage workers. Men decrease their labor supply in response to any type of disadvantageous inequality, whereas disadvantaged women reduce their labor supply only if the low-wage is due to gender-discriminatory chances.

Our study provides three main contributions to the literature. First, it is the first to investigate the causal effect of unfair chances on labor supply decisions of workers. Our finding that the fairness of chances from an unspecified source does not affect labor supply stands in contrast to the empirical literature on unfair chances and income redistribution (e.g., Bolton et al., 2005; Krawczyk and Le Lec, 2010; Brock et al., 2013; Cappelen et al., 2013). Specifically, whereas the distribution of initial chances has been shown to influence redistribution decisions, we find that it has no impact on workers' labor supply decisions. This suggests that the response to unfair chances depends on the context.

Second, our study also provides the first evidence of the causal impact of gender discrimination on labor supply decisions. Our finding that unfair chances based on gender have a 
large negative impact on labor supply is consistent with literature in medicine and psychology, suggesting that discrimination imposes a specific psychological cost (e.g., Pascoe and Smart Richman, 2009). This adds to the few economic studies showing that (ethnic minority) workers modify their behavior when discriminated (Parsons et al., 2011; Glover et al., 2017), making them appear less productive for employers. Our study is the only one that identifies the effect of discrimination while controlling for changes in monetary incentives resulting from the presence of discrimination.

A third contribution of our study is to the research on gender differences in labor markets more generally (Croson and Gneezy, 2009; Niederle, 2016). Our result that men reduce their labor supply in reaction to unequal wages from fair and unfair chances coming from an unspecified source, whereas women do not, is consistent with the findings of Bracha et al. (2015). They, however, do not study the effect of unfair chances. In addition, we show that also women decrease their labor supply if they face lower wages that are the result of gender discrimination.

Finally, an important implication of our study is that it suggests a novel and complementary explanation for the gender gap in earnings. Goldin (2014) and Blau and Kahn (2017) review the literature on the earnings gender gap and conclude that the modern gender gap is mostly explained by the lower labor supply of women. The standard explanation for this lower labor supply is that women value temporal flexibility more than men, plausibly because they have to bear greater household responsibilities (e.g., Goldin, 2014; Wiswall and Zafar, 2017). Importantly, we provide evidence that the experience of gender discrimination itself can reduce labor supply. Not accounting for this channel might lead to misjudgment of the impact of discrimination and ill-advised policies. The identified channel may also affect the gender earnings gap in the manner of a self-fulfilling prophecy. Since the labor market offers high returns to long work hours, a lower labor supply can be both a reaction to discrimination and a rationale for employers to pay women less than men.

The rest of the paper is organized as follows. Section II situates our research in the literature, Section III presents the theoretical framework, Section IV describes the study design, Section V advances the hypotheses, Section VI details the results, Section VII discusses our findings and their implications, and Section VIII briefly concludes.

\section{Related Literature}

\section{II.A. Unequal Wages}

A stream of literature suggests that wage differentials perceived as unfair hamper the work morale of workers (Adams, 1965; Akerlof and Yellen, 1990; Pfeffer and Langton, 1993; Bew- 
ley, 1999). Empirical evidence shows that unequal wages for similar work indeed negatively affect several labor outcomes. For instance, wage inequality decreases work satisfaction and increases job searches among disadvantaged workers (Card et al., 2012) and hurts their productivity (Gächter and Thöni, 2010; Cohn et al., 2014; Ockenfels et al., 2014). ${ }^{3}$

We discuss here in more detail those studies that investigate the effect of unequal wages on labor supply, which is our variable of interest. Bracha et al. (2015) report a laboratory experiment where workers are paid piece-rate wages in an individual task and have to decide for how long to work. If no justification is provided, unequal wages decrease labor supply of male but not of female low-pay workers. High-pay workers' labor supply does not respond to wage inequality, irrespective of gender. Breza et al. (2018) conduct a field experiment with male workers in an Indian firm. Workers work individually in small teams in which wage inequality is manipulated. If workers do not observe other workers' productivity, then inequality decreases labor supply of low-pay and high-pay workers as well as the productivity of low-pay workers. However, wage inequality has no effect if it reflects observable productivity differences. Dube et al. (2019) exploit a natural experiment caused by changes in the wage structure of a large American firm. They find that workers arbitrarily receiving a low relative pay after the change were more likely to quit, whereas workers with a higher relative pay did not change their behavior. Those important studies are informative about the effect of wage inequality on labor supply decisions. However, they do not examine the role of chances or discrimination as a reason for wage differences and how it may affect labor supply.

\section{II.B. Unfair Chances}

Economists have long considered the welfare implications of assessing inequality in terms of ex ante chances and ex post outcomes (Harsanyi, 1955; Diamond, 1967; Hammond, 1981; Epstein and Segal, 1992; Fleurbaey, 2010). Models of social preferences have also recently incorporated a dislike for unequal chances, usually referred to as a concern for ex ante or procedural fairness (Karni and Safra, 2002; Bolton et al., 2005; Trautmann, 2009; Krawczyk, 2011; Saito, 2013). A number of laboratory experiments have lent empirical support to the notion that individuals take into consideration the fairness of chances when making distributive decisions (Bolton et al., 2005; Karni et al., 2008; Krawczyk and Le Lec, 2010; Krawczyk, 2010; Brock et al., 2013; Cappelen et al., 2013; Andreoni et al., 2016; Grimalda et al., 2016; Trautmann and

\footnotetext{
${ }^{3}$ However, individuals might accept or demand inequality on the grounds of equity (Konow, 2000). For example, wage differentials could be viewed as equitable if they reflect observable productivity differentials (Abeler et al., 2010; Breza et al., 2018). This could even be the case if differences in productivity are possible, but unobserved (Charness and Kuhn, 2007).
} 
van de Kuilen, 2016; Cettolin and Riedl, 2016; Miao and Zhong, 2018). However, how ex ante chances influence the labor decisions of workers has not been investigated. ${ }^{4}$

\section{II.C. Gender Discrimination}

Women face a gender gap in earnings, have lower promotion chances, are less present in highpaid jobs, work less hours, work more part time, and have a lower labor participation (for overviews, see, Altonji and Blank, 1999; Riach and Rich, 2002; Goldin, 2014; Blau and Kahn, 2017). A number of studies suggest that demand-side gender discrimination plays an important role in explaining women's disadvantaged labor market position (see, e.g., Bertrand and Duflo, 2017; Neumark et al., 1996; Goldin and Rouse, 2000; Sarsons et al., 2019). ${ }^{5}$

Interestingly, potential supply-side effects of discrimination are much less studied. Parsons et al. (2011) present evidence from American baseball showing that minority players change their behavior in response to discrimination by officials. Glover et al. (2017) show that ethnically-biased managers in a large French grocery chain decrease minority workers' productivity and labor supply. A field experiment of Ibañez and Riener (2018) examines some aspects of gender discrimination (Affirmative Action for women) on job applications. In those studies, discrimination changes the monetary incentives for workers who are discriminated, so that the response to discrimination is entangled with the change in incentives.

Studies in medicine and psychology show that discrimination is correlated with serious negative consequences for physical and mental well-being. In a meta-analytic review, Pascoe and Smart Richman (2009) link discrimination to a range of psychological issues, such as anger, stress, anxiety, distress, and low general wellbeing, all of which we can reasonably expect to considerably lower one's work satisfaction. However, the reviewed studies do not investigate the impact on workers' labor decisions.

\section{Theoretical Framework}

We adapt the framework of Card et al. (2012) and Breza et al. (2018) to model how workers may react to unequal wages, unfair chances, and gender discrimination. In the original model, wage inequality between workers engaged in the same work decreases work satisfaction or morale, which translates into lower marginal utility from work and thus into lower labor supply. Our

\footnotetext{
${ }^{4}$ Organizational psychologists have studied a related concept referred to as procedural justice. According to one prominent form of procedural justice, procedures are fair to the extent that decisions are "consistent" and without "bias" (see, e.g., Leventhal et al., 1980; Skarlicki and Folger, 1997).

${ }^{5}$ In this literature, taste-based discrimination (Becker, 1971) and statistical discrimination (Phelps, 1972; Arrow, 1973) are the two most discussed forms of discrimination. Other forms include language discrimination (Lang, 1986), implicit discrimination (Bertrand et al., 2005), attention discrimination (Bartoš et al., 2016), and stereotypes (Bordalo et al., 2016).
} 
model is an extension that also accounts for chances in the process leading to unequal wages. That is, unfair chances are also assumed to decrease marginal utility from work. To explore the role of gender discrimination, we assume that individuals are more averse to unfair chances caused by gender discrimination than to unfair chances coming from an unspecified source. ${ }^{6}$ We use this model to derive most of our hypotheses, which are formulated in Section V.

Consider two workers, $i$ and $j$, engaged in the same work receiving piece-rate wages $w_{i}$ and $w_{j}$, which are known to both workers. There is no interaction between the two workers. A worker, say $i$, chooses labor supply $l_{i}$ by taking into account his or her own wage, the wage of the other worker $j$, the chances that lead to their respective wages, and the cost of providing labor.

The modeling of marginal disutility created by ex post wage inequality is inspired by Fehr and Schmidt (1999) and is also used in Breza et al. (2018). It is denoted $P_{i}$ and given by

$$
P_{i}\left(w_{i}, w_{j}\right)=\alpha_{i} \max \left\{w_{j}-w_{i}, 0\right\}+\beta_{i} \max \left\{w_{i}-w_{j}, 0\right\}
$$

where the first term on the right-hand side measures the marginal disutility from disadvantageous wage inequality and the second term the marginal disutility from advantageous wage inequality, with $\alpha_{i}>\beta_{i}>0 .^{7}$ That is, wage inequality produces a marginal disutility, and this marginal disutility is greater for disadvantageous inequality than for advantageous inequality.

The marginal disutility created by unfair chances, denoted by $A_{i}$ for ex ante inequality, is inspired by Saito $(2013)^{8}$ and takes the form

$$
A_{i}\left(E w_{i}, E w_{j}\right)=\alpha_{i}^{\prime} \max \left\{E w_{j}-E w_{i}, 0\right\}+\beta_{i}^{\prime} \max \left\{E w_{i}-E w_{j}, 0\right\}
$$

where $E w_{i}$ and $E w_{j}$ denote expected wages. Similar to equation (1), here the first term on the right-hand side reflects the marginal disutility from disadvantageous expected wage inequality, and the second term that from advantageous expected wage inequality. As above we assume that $\alpha_{i}^{\prime}>\beta_{i}^{\prime}>0$ but we allow for $\alpha_{i} \neq \alpha_{i}^{\prime}$ and $\beta_{i} \neq \beta_{i}^{\prime}$. That is, the disutility weights placed on wage inequality and unfair chances may differ.

We embed the aversion to unequal wages and the aversion to unfair chances described in equations (1) and (2) in the labor supply decision in the following way. A worker $i$ chooses

\footnotetext{
${ }^{6}$ Unlike Breza et al. (2018) and in line with our experimental implementation, we rule out moral hazard and assume that work effort is fully contractible.

${ }^{7}$ This assumption is based on the empirical evidence reported in Bracha et al. (2015), Breza et al. (2018) and Dube et al. (2019) which suggests that, on average, $\alpha_{i}>\beta_{i}=0$ or $\alpha_{i}>\beta_{i}>0$. The literature on social preferences often makes the weaker assumption $\alpha_{i} \geq \beta_{i} \geq 0$ (e.g., Fehr and Schmidt, 1999). In our model, if $\alpha_{i}=\beta_{i}>0$, then the effect of unequal wages on marginal disutility is the same for advantaged and disadvantaged workers. If $\alpha_{i}=\beta_{i}=0$, then the problem collapses to standard selfish preferences and unequal wages do not affect the morale of workers.

${ }^{8}$ For earlier theoretical work combining social preferences and the effect of (un)fair chances, see Bolton et al. (2005) and Trautmann (2009).
} 
labor supply $l_{i}$ in order to maximize the utility function

$$
U_{i}\left(w_{i}, w_{j}, l_{i}\right)=w_{i} l_{i}-P_{i}\left(w_{i}, w_{j}\right) l_{i}-A_{i}\left(E w_{i}, E w_{j}\right) l_{i}-\frac{l_{i}^{2}}{2} .
$$

In equation (3), the first term on the right-hand side corresponds to the utility of monetary earnings derived from working, the second term is the disutility created by wage inequality, and the third term reflects the disutility created by unfair chances. The final term is the utility cost of providing labor. ${ }^{9}$

Assuming an interior solution, the optimal labor supply is given by

$$
l_{i}^{*}=w_{i}-P_{i}\left(w_{i}, w_{j}\right)-A_{i}\left(E w_{i}, E w_{j}\right)
$$

Given our assumptions about $\alpha_{i}, \beta_{i}, \alpha_{i}^{\prime}$ and $\beta_{i}^{\prime}$, the term $P_{i}\left(w_{i}, w_{j}\right)$ is strictly positive when wages are unequal and the term $A_{i}\left(E w_{i}, E w_{j}\right)$ is strictly positive when chances are unfair. Thus, unequal wages and unfair chances both reduce the optimal labor supply. ${ }^{10}$ Disadvantageous inequality reduces the optimal labor supply more than advantageous inequality does because of $\alpha_{i}>\beta_{i}$ and $\alpha_{i}^{\prime}>\beta_{i}^{\prime}$.

Regarding gender discrimination, we posit that it translates into further marginal disutility from unequal wages or unfair chances. As before, we assume that the marginal disutility caused by discrimination is greater for disadvantaged than for advantaged workers. That is, gender discrimination in chances would increase $\alpha_{i}^{\prime}$ and $\beta_{i}^{\prime}$, and would increase $\alpha_{i}^{\prime}$ more than $\beta_{i}^{\prime}$. Therefore, unfair chances based on gender discrimination reduce the optimal labor supply more than unfair chances based on an unspecified source and the labor supply reduction is greater for disadvantaged than for advantaged workers.

Before translating these theoretical considerations into testable hypotheses in Section V, we first present our study design and experiment.

\section{Study Design}

\section{IV.A. Experiment}

We hired workers on an online labor platform for performing a real effort task, which consisted of entering lines of random characters. ${ }^{11}$ Each worker was assigned the same task and carried it out individually, entering one line at a time. The payment was on a piece-rate basis, that

\footnotetext{
${ }^{9}$ For simplicity, we assume a quadratic cost function. The hypotheses derived from the model stay qualitatively the same when assuming any other strictly increasing and strictly convex cost function.

${ }^{10}$ Equation (4) assumes an interior solution. If the optimal labor supply is a corner solution-zero or maximum labor supply-altering the inequality of wages or the unfairness of chances may not affect the optimal labor supply.

${ }^{11}$ Here we describe the design of the experiment. The online labor market and the pros and cons of using it for research purposes are described and discussed in more detail in Section IV.B below.
} 
is, a worker received a fixed payment per correctly entered line. If a mistake was made when entering a line, the worker was informed and had to correct it before proceeding to the next line. The length of the lines increased with the number of lines completed, which made the task increasingly harder over time. ${ }^{12}$ Each worker decided individually how many lines to enter. A worker could stop working at any time by leaving the experiment. Workers were informed about this and that they could not reenter the experiment once they had left. They were also instructed that they could work for at most 65 minutes. The number of lines entered is our measure of labor supply.

Each worker was randomly assigned to one payment scheme and anonymously paired with another worker in the same scheme who was engaged in the exact same task on the platform. Each worker in a pair was first informed about the procedure that would lead to his or her own wage and the wage of the other worker. Thereafter, each of the two workers was informed about his or her own resulting wage and the wage of the other worker. Thus, workers only started working after any uncertainty about their own and the other worker's wage was resolved. Figure 1(a) provides a screenshot example of what workers saw when they were informed about the procedure leading to the wages, and Figure 1(b) shows a screenshot example of what they saw when informed about the resulting wages. To emphasize the piece-rate nature of the wage, it was described as a "payment per line."

Table 1: Wages and Chances of Two Workers in a Pair for each Payment Scheme

\begin{tabular}{rccc}
\hline \hline Payment Scheme & $\begin{array}{c}\text { Wage of Worker, } \\
\text { Wage of Other Worker }\end{array}$ & $\begin{array}{c}\text { Chance of Worker, } \\
\text { Chance of Other Worker }\end{array}$ & $\begin{array}{c}\text { Source of } \\
\text { Chances }\end{array}$ \\
\hline EQLOW & $£ 0.03, £ 0.03$ & - & - \\
EQHIGH & $£ 0.06, £ 0.06$ & - & - \\
UNEQFAIR & $£ 0.03, £ 0.06$ & $50 \%, 50 \%$ & Unspecified \\
UNEQUNFAIR & $£ 0.03, £ 0.06$ & $25 \%, 75 \%$ & Unspecified \\
UNEQDISCR & $£ 0.03, £ 0.06$ & $25 \%, 75 \%$ & Gender Discrimination \\
\hline
\end{tabular}

Note: Chances are to receive the high wage $(£ 0.06)$.

Table 1 summarizes the five payment schemes (treatments) we employ. The schemes determine, within a worker pair, the wages and the procedure creating these wages. In the schemes EQLOW and EQHIGH, no chances are involved and both workers receive either the low piecerate wage of $£ 0.03$ or the high piece-rate wage of $£ 0.06$. These treatments serve as controls for the labor supply effect of receiving a low or a high wage when inequality in wages and procedures is absent. In the three other schemes, the two workers in a pair face chances to obtain the

\footnotetext{
${ }^{12}$ The number of characters contained in a line ranged from 10 at the start to 26 at the end. We implemented this to mimic an increasing and convex cost of labor supply. There was a maximum of 85 lines and workers were not informed about this beforehand (see Figure A1 in Section A of the Appendix for two screenshots of the task). Further details on the task can be found in the instructions of the experiment, which are provided in Section B of the Appendix.
} 


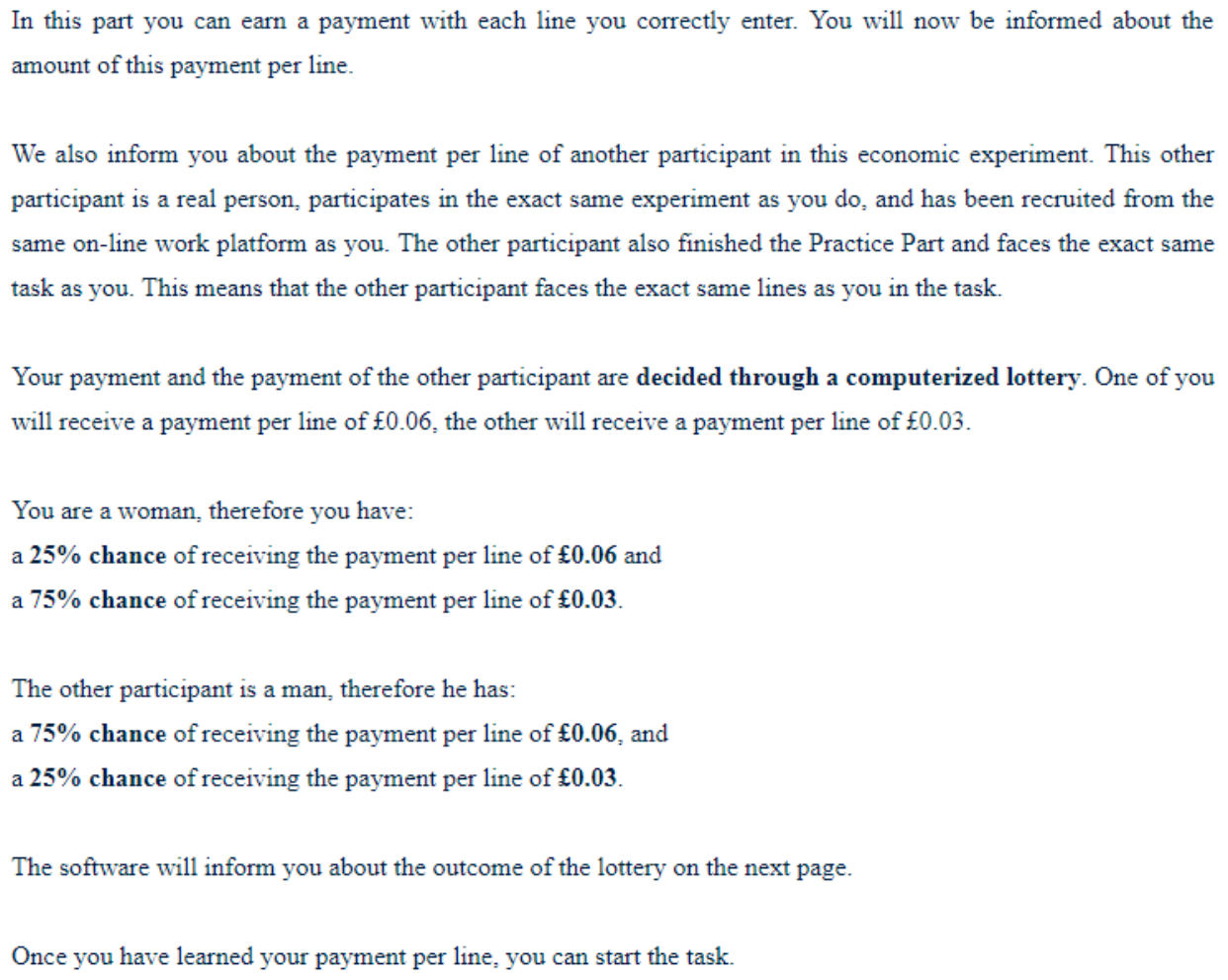

(a) Presentation of the Procedure Determining the Wages (Payment Scheme UNEQDISCR)

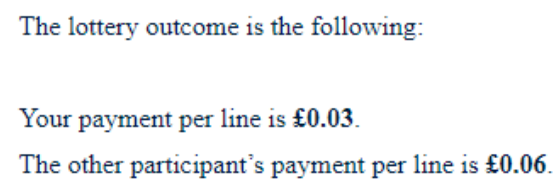

(b) Presentation of the Wages (Payment Scheme UNEQDiSCR)

Figure 1: Presentation of the Procedure Determining the Wages and Presentation of Wages

high or the low wage in a lottery. The lottery draw is dependent such that one worker receives the high wage and the other worker receives the low wage. In UNEQFAIR both workers have a fair chance of $50 \%$ to receive the high wage, whereas in UNEQUNFAIR one worker faces a low chance of $25 \%$ and the other worker faces a high chance of $75 \%$ to receive the high wage. In both of these schemes we do not inform workers about the reason why the chances are allocated in this manner. In contrast, in the scheme UNEQDISCR the unfair chances explicitly discriminate one gender over the other. That is, one worker in the pair is informed that she (he) faces a $25 \%$ chance of receiving the high wage because she (he) is a woman (man), and that the other worker faces a $75 \%$ chance of receiving the high wage because he (she) is a man 
(woman). In this treatment, in half of the cases men face higher chances and in the other half women face higher chances. ${ }^{13}$

At the start of the experiment, a worker electronically signed an informed consent form and then read the instructions. Each worker had to correctly answer nine comprehension questions and go through a practice phase to become familiar with the task. Only thereafter was the worker assigned to a payment scheme and informed about the procedure leading to the wages in his or her worker pair. After having learned his or her own wage and the wage of the other worker in the pair, a worker could start working on the task.

\section{IV.B. Online Labor Markets}

We recruit workers on the UK-based online platform Prolific (www.prolific.ac). The use of such online labor markets for experiments has gained in popularity among economists in recent years. ${ }^{14}$ For our research the use of an online platform provides important advantages over a laboratory experiment or a field experiment inside a firm, but it also has some potential shortcomings. In what follows we discuss these advantages and how we deal with potential disadvantages.

The first advantage is that the online platform greatly reduces the possibility of peer effects, because workers on the platform do not interact with each other in any way during the task and can quit working without other workers noticing it. On the platform there is no channel through which workers could communicate with each other and to our knowledge also no informal website exists through which this happened. There are also restrictions on accounts and on participation per IP address, which we discuss below. Moreover, only a subset of registered potential workers meeting our criteria are invited to participate, which limits the probability that registered participants who know each other are invited. ${ }^{15}$ In a post-experiment questionnaire,

\footnotetext{
${ }^{13}$ Workers were not informed about this balance.

${ }^{14}$ Examples include Pallais (2014) on inexperienced workers, Kuziemko et al. (2015) on redistribution preferences, Gilchrist et al. (2016) on employer-employees relationships, Pallais and Sands (2016) and Horton (2017a) on labor market referrals and recommendations, Bordalo et al. (2016) on stereotypes, Horton (2017b) on minimum wages and employment, Lyons (2017) on diversity and production in teams, Coffman et al. (2016) on anti-gay sentiments, Coffman et al. (2017) and Sarsons et al. (2019) on gender discrimination, and De Quidt et al. (2018) on experimenter demand effects. Horton et al. (2011), Arechar et al. (2018), and Snowberg and Yariv (2018) report that common economic games and elicited behavior in online and laboratory experiments provide qualitatively similar results. Bohren et al. (2018) also use an online scientific platform to study gender discrimination, where individuals are not paid but volunteer. Furthermore, several studies use existing labor data from online platforms, e.g., Ghani et al. (2014), Stanton and Thomas (2015), and Dube et al. (2018). Finally, see Chen and Konstan (2015) for a survey of several experiments on different platforms.

${ }^{15}$ Our criteria were: UK is the country of residence, registration as a man or woman, and an approval rate of at least $80 \%$ for previous participation in other studies. The number of registered individuals meeting our criteria was greater than 6,000 . Workers meeting the selection criteria could register for our experiment without receiving an invitation email if they logged in on the website and selected our experiment, provided that our required number of workers had not been attained. The fact that our experiment was almost fully conducted within 24 hours limits this possibility. Importantly, there is no gain for workers from discussing or working with someone else during our experiment due to the nature of the task.
} 
$95.4 \%$ of workers reported that they did not discuss the task with someone else when deciding whether or not to participate, and a similar number (97.4\%) declared that they completed the task without the help of someone else. In a field experiment inside a firm, in contrast, workers might communicate with others, observe how much others work, and news might spread that there exist different payment schemes. Also, in the laboratory it is likely that participants receive cues about the behavior of others because the typical experiment has multiple participants inside the same room. ${ }^{16}$

The second advantage is that it enables us to recruit a relatively large number of workers at reasonable costs, which increases the statistical power to detect differences in labor supply across payment schemes. Moreover, the online platform provides access to a pool of workers with diverse demographic backgrounds, which arguably increases external validity relative to a sample of undergraduate students. The third advantage is that, with approval from an ethical committee, we were allowed to engage in gender discrimination on the platform. This would have been difficult to implement in a field experiment inside a firm for legal and other reasons.

We took precautions to minimize potential problems that are associated with conducting experiments using online platforms. As participants have to read and understand the instructions of the experiment without support, it might be that they do not read them carefully enough or do not fully understand them. To ensure proper reading and understanding, we required participants to correctly answer nine exhaustive comprehension questions about the instructions. Participants who failed a question three times were automatically excluded and did not participate in the experiment. Another issue might be that participants do not fully trust that the instructions are truthful because online platforms do not necessarily have the reputation to be deception-free. To minimize this possibility, we made clear in the invitation to the experiment and again in the instructions that we do not use deception and that this is the standard in economic experiments. In a post-experiment questionnaire, participants report that they understood the instructions well and that they largely trusted that the instructions were truthful. ${ }^{17}$

\footnotetext{
${ }^{16}$ We have considered to run the experiment in the laboratory, but decided against it because it would have been very difficult and expensive to avoid peer effects. For instance, any worker who stops working and leaves the laboratory is likely to be noticed by other workers. An alternative would have been to have only one worker at a time in the laboratory, but this causes at least three problems: (1) it is extremely time consuming to collect a large enough number of observations, (2) it may open the door to session effects (Fréchette, 2012), and (3) information regarding the experiment can spread among potential participants, because the experiment would take place over a long time period.

${ }^{17}$ The comprehension questions also prevented automatic programs (robots) from entering our experiment by passing as human workers. Importantly, exclusion of subjects who failed was independent of the payment schemes, because they were excluded from the experiment before they were allocated to a scheme. Participants reported how well they understood the instructions on a Likert scale from 1 (Not at All) to 7 (Very Well) with a mean answer of $6.27(\mathrm{SD}=1.04, N=1,254)$ and reported how much they trusted the instructions on a Likert scale from 1 (Not at All) to 7 (Completely) with a mean answer of $5.94(\mathrm{SD}=1.42, N=1,254)$.
} 
Another concern might be that workers participate more than once, because it is not possible to directly verify the identity of participants. To minimize this possibility, the platform employs a number of measures to prevent duplicate accounts. These measures include limiting participation in an experiment to once per account, limiting the number of accounts per IP address, limiting participation in an experiment to once per IP address, requiring a unique non-voice over IP phone number per account, and limiting accounts to one per Paypal or Circle account for payment. ${ }^{18}$ The platform also forbids the use of VPNs and tracks changes in the country of connection and other suspicious participation patterns.

\section{IV.C. Procedures and Demographics}

Workers on the online platform were invited via email in January 2018 and freely decided whether or not to participate. ${ }^{19}$ In total 1,271 workers successfully completed the comprehension questions and participated in the experiment. On average, those workers spent 26.35 (SD = 15.56) minutes in the experiment, and were paid $2.64(\mathrm{SD}=1.53)$ pounds. Table 2 summarizes their demographic characteristics.

Table 2: Demographic Characteristics of Workers

\begin{tabular}{rc}
\hline \hline Demographic Characteristic & Mean (SD) or Percentage \\
\hline Age & $38(12)$ \\
Task Experience on Platform & $141(176)$ \\
Woman & $50 \%$ \\
Student & $16 \%$ \\
UK National & $93 \%$ \\
Caucasian/White & $88 \%$ \\
Employed Full-Time & $50 \%$ \\
Employed Part-Time & $20 \%$ \\
Job Seeker & $18 \%$ \\
Not in Paid Work & $6 \%$ \\
Other Work Situation & $5 \%$ \\
\hline
\end{tabular}

Note: $N$ varies between 1,263 and 1,271 by characteristic because we could not obtain some characteristics from the platform for a few workers.

Not everyone who logged into the experiment actually participated. Specifically, the sample does not include the following individuals. First, the software automatically prevented 281 in-

\footnotetext{
${ }^{18}$ Our study was registered using two separate experiments on the platform, one only accessible to men and one only accessible to women. This is a feature of the platform, which requests that filtering by gender be done in this manner. This means that participation in the study was limited to one man and one woman per IP address (using gender reported on the platform). A total of $6 \%$ of participants had the same IP address at the time of their participation as another participant of the other gender. The address can be the same for different reasons, e.g., workers participate from the same house, public space or workplace. Note that Paypal and Circle also take steps to prevent duplication of accounts.

${ }^{19}$ The invitation email can be found in Section B of the Appendix.
} 
dividuals who did not complete the comprehension questions from being assigned to a payment scheme and starting the task. Second, eight individuals quit at the end of the comprehension questions or during the practice phase. Third, 48 individuals were excluded because they exceeded the time limit. ${ }^{20}$ Fourth, seven individuals where removed because the reported gender in the experiment did not correspond to their gender in the platform database.

\section{Hypotheses}

Our four hypotheses were registered before the execution of the experiment ${ }^{21}$ and all refer to workers who do not beat the odds. These are all low-wage workers who faced a payment scheme with (i) equal low wages without chances, (ii) fair chances to receive a high wage, or (iii) low chances to receive a high wage, and all high-wage workers who faced a payment scheme with (i) equal high wages without chances, (ii) fair chances to receive a high wage, or (iii) high chances to receive a high wage. We only consider those workers because too few workers beat the odds for an informative statistical analysis. The first three hypotheses are based on the optimal labor supply derived in the theoretical framework presented in Section III. ${ }^{22}$

Table 3: Predicted Labor Supply in Each Payment Scheme

\begin{aligned} & \hline \hline Low-Wage Worker $i \\ &$\cline { 2 - 2 } Payment Scheme \\ & \hline EQLOW $l_{i}^{E}\left(w_{l}\right)=w_{l} \\ &$ UNEQFAIR $l_{i}^{F}\left(w_{l}\right)=w_{l}-P_{i}\left(w_{l}, w_{h}\right) \\ &$ UNEQUNFAIR $l_{i}^{U}\left(w_{l}\right)=w_{l}-P_{i}\left(w_{l}, w_{h}\right)-A_{i}\left(E w_{l}, E w_{h}\right) \\ &$ UNEQDISCR $l_{i}^{D}\left(w_{l}\right)=w_{l}-P_{i}\left(w_{l}, w_{h}\right)-A_{i}^{D}\left(E w_{l}, E w_{h}\right) \\ &$\hline High-Wage Worker $i \\ &$\cline { 2 - 2 } Payment Scheme \\ & \hline EQHIGH $l_{i}^{E}\left(w_{h}\right)=w_{h} \\ &$ UNEQFAIR $l_{i}^{F}\left(w_{h}\right)=w_{h}-P_{i}\left(w_{h}, w_{l}\right) \\ &$ UNEQUNFAIR $l_{i}^{U}\left(w_{h}\right)=w_{h}-P_{i}\left(w_{h}, w_{l}\right)-A_{i}\left(E w_{h}, E w_{l}\right) \\ &$ UNEQDISCR $l_{i}^{D}\left(w_{h}\right)=w_{h}-P_{i}\left(w_{h}, w_{l}\right)-A_{i}^{D}\left(E w_{h}, E w_{l}\right) \\ &$\hline\end{aligned}

Note: The predicted labor supply of a worker $i$ is given by Equation (4) in Section III: $l_{i}^{*}=w_{i}-P_{i}\left(w_{i}, w_{j}\right)-A_{i}\left(E w_{i}, E w_{j}\right)$, where the term $A_{i}^{D}\left(E w_{i}, E w_{j}\right)$ indicates the presence of genderdiscriminatory chances $\left(A_{i}^{D}\left(E w_{i}, E w_{j}\right)>A_{i}\left(E w_{i}, E w_{j}\right)\right)$. Predictions are for workers who do not beat the odds.

\footnotetext{
${ }^{20}$ These individuals went over the time limit of 65 minutes despite being explicitly forbidden from doing so in the experiment description on the platform, and being provided with a time countdown from 65 to 0 minutes during their work to remind them of the time limit.

${ }^{21}$ American Economic Associations Randomized Control Trials Registry (ID: AEARCTR-0002655).

${ }^{22}$ The theoretical optimal labor supply is based on the interior solution. We conducted a pilot study in advance to ensure that the parameters of the experiment (e.g., piece-rate wages, length of lines, duration) do not produce too many corner outcomes where workers do not work at all or finish all tasks. As we will see later in Section VI, workers in the experiment indeed overwhelmingly choose an interior outcome.
} 
Table 3 shows the predicted labor supply in each payment scheme, in the upper part for low-wage workers, and in the lower part for high-wage workers. Recall that, for unequal wages and unfair chances, $P_{i}$ and $A_{i}$ take on positive values, and for unfair chances, $A_{i}$ takes on smaller values than $A_{i}^{D}$. From the table, it then follows straightforwardly that,

for a low-wage worker $i$,

$$
l_{i}^{E}\left(w_{l}\right)>l_{i}^{F}\left(w_{l}\right)>l_{i}^{U}\left(w_{l}\right)>l_{i}^{D}\left(w_{l}\right)
$$

and for a high-wage worker $i$,

$$
l_{i}^{E}\left(w_{h}\right)>l_{i}^{F}\left(w_{h}\right)>l_{i}^{U}\left(w_{h}\right)>l_{i}^{D}\left(w_{h}\right) .
$$

This leads to our first two hypotheses.

HyPOTHESIS 1, LOW-WAGE WORKERS: For low-wage workers, labor supply ranks across payment schemes as follows: EQLOW > UNEQFAIR > UNEQUNFAIR > UNEQDISCR.

HYPOTHESIS 2, High-WAGE WORKERS: For high-wage workers, labor supply ranks across payment schemes as follows: EQHIGH > UNEQFAIR > UNEQUNFAIR > UNEQDISCR.

Recall that we assume that being in a disadvantageous position (low wage or low chance of receiving the high wage) creates a larger marginal disutiliy from inequality than being in an advantageous position (high wage or high chance of receiving the high wage). ${ }^{23}$ We also assume that gender-discriminatory unfair chances are disliked more than unfair chances from an unspecified source, and that negative discrimination is worse than positive discrimination. This implies that, at a given wage, unequal wages, unfair chances, and gender discrimination each decrease the optimal labor supply more for a low-wage worker than for a high wage worker. More formally, it holds that ${ }^{24}$

$$
\begin{aligned}
& l_{i}^{E}\left(w_{l}\right)-l_{i}^{F}\left(w_{l}\right)>l_{i}^{E}\left(w_{h}\right)-l_{i}^{F}\left(w_{h}\right), \\
& l_{i}^{F}\left(w_{l}\right)-l_{i}^{U}\left(w_{l}\right)>l_{i}^{F}\left(w_{h}\right)-l_{i}^{U}\left(w_{h}\right), \text { and } \\
& l_{i}^{U}\left(w_{l}\right)-l_{i}^{D}\left(w_{l}\right)>l_{i}^{U}\left(w_{h}\right)-l_{i}^{D}\left(w_{h}\right) .
\end{aligned}
$$

Our third hypothesis is therefore as follows.

\footnotetext{
${ }^{23}$ See Section III, Equations (2) and (3) together with $\alpha_{i}>\beta_{i}$ and $\alpha_{i}^{\prime}>\beta_{i}^{\prime}$.

${ }^{24}$ To obtain these three inequalities we use Table 3. For the first inequality we have $l_{i}^{E}\left(w_{l}\right)-l_{i}^{F}\left(w_{l}\right)=P_{i}\left(w_{l}, w_{h}\right)$ and $l_{i}^{E}\left(w_{h}\right)-l_{i}^{F}\left(w_{h}\right)=P_{i}\left(w_{h}, w_{l}\right)$. Because $\alpha_{i}>\beta_{i}$, it holds that $P_{i}\left(w_{l}, w_{h}\right)>P_{i}\left(w_{h}, w_{l}\right)$. The two other inequalities are obtained in the same manner.
} 
Hypothesis 3, Disadvantage vs. Advantage: For each of the following comparisons, the labor supply decrease is greater for low-wage workers than for high-wage workers: UNEQFAIR vs. EQLOW/EQHigh, UNEQUNFAIR vs. UNEQFAIR, and UNEQDiscr vs. UNEQUnFAIR.

As gender discrimination is generally experienced by women rather than by men in society, discriminating against women might have a different effect on labor supply than discriminating against men. However, the a priori direction of the difference is not clear. On the one hand, discrimination against women worsens existing inequalities and may be especially painful for them, and men might perceive discrimination against them as a justified compensation for everday discrimination of women. This might lead to a strong negative labor supply reaction by women but a positive or neutral one by men. On the other hand, women may have weaker negative labor supply reactions because they are used to discrimination, and men may be habituated to higher chances so that their new experience of lower chances may be especially frustrating and thus strongly decrease their labor supply. Therefore, our fourth hypothesis, which concerns this possible gender difference, is not directed and we state the null hypothesis.

Hypothesis 4, Gender and Negative Discrimination: The difference in labor supply between UNEQUNFAIR and UNEQDISCR is equal for both genders.

\section{Results}

In this section we first report descriptive statistics regarding labor supply under the different payment schemes followed by tests of our four hypotheses. Thereafter, we present some exploratory analyses on potential gender differences beyond our hypotheses and on labor supply responses at the extensive and intensive margins. Recall that we measure labor supply as the number of lines entered during the experiment and that workers could stop working at any time.

\section{VI.A. Descriptive Statistics}

Figure 2 and Table 4 summarize labor supply by type of worker and payment scheme. ${ }^{25}$ The left part of the figure and table present the labor supply of low-wage workers, and the right part that of high-wage workers. For low-wage workers, the scheme EQLow generates the largest mean labor supply, followed by UNEQUNFAIR and UNEQFAIR (with little difference between

\footnotetext{
${ }^{25}$ Workers beating the odds are excluded unless we state otherwise (see Section V).
} 
them), and then by UNEQDISCR. For high-wage workers, all schemes produce a comparable mean labor supply. ${ }^{26}$

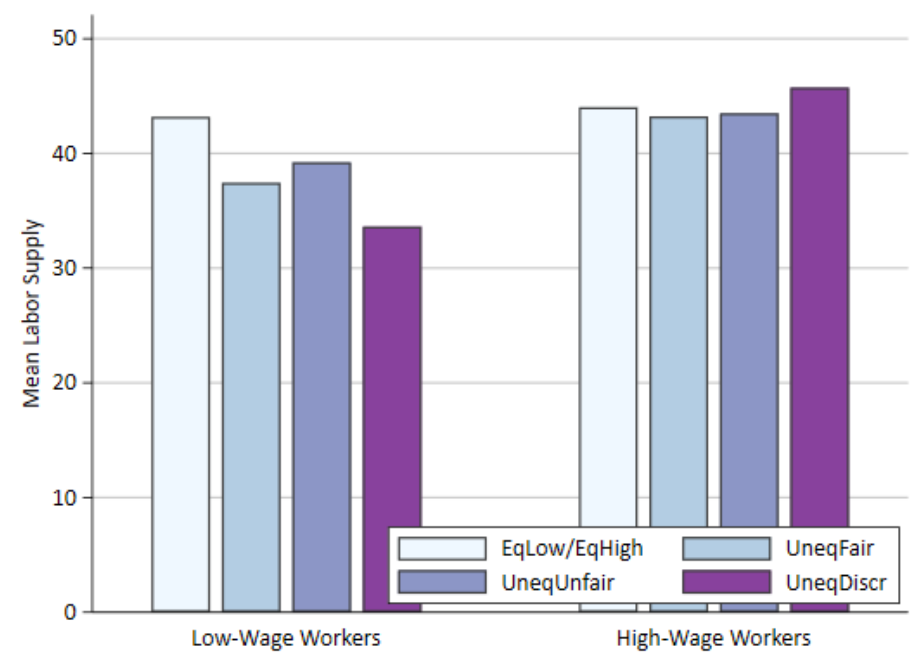

Figure 2: Mean Labor Supply per Payment Scheme

Note: Labor supply is measured by the number of lines completed and ranges from 0 to $85 . N$ ranges from 127 to 145 workers per payment scheme.

Table 4: Labor Supply per Payment Scheme

\begin{tabular}{|c|c|c|c|c|c|c|c|c|c|c|}
\hline & \multicolumn{5}{|c|}{ Low-Wage Workers } & \multicolumn{5}{|c|}{ High-Wage Workers } \\
\hline & Mean & SD & Min. & Max. & $N$ & Mean & SD & Min. & Max. & $N$ \\
\hline EQLOW/EQHIGH & 43.20 & 27.63 & .04 & .16 & 128 & 44.03 & 28.93 & .04 & .20 & 128 \\
\hline UNEQFAIR & 37.44 & 29.16 & .06 & .17 & 125 & 43.23 & 29.64 & .03 & .20 & 127 \\
\hline UNEQUNFAIR & 39.22 & 27.76 & .04 & .15 & 143 & 43.50 & 28.85 & .02 & .20 & 143 \\
\hline UNEQDISCR & 33.62 & 26.41 & .08 & .11 & 143 & 45.74 & 26.72 & .02 & .16 & 145 \\
\hline
\end{tabular}

Note: Labor supply is measured by the number of lines completed and ranges from 0 to 85 . Min. and Max. indicate the percentage of workers completing the minimum and maximum number of lines.

\section{VI.B. Test of Hypotheses}

To test our hypotheses we employ non-parametric rank tests as well as Tobit regressions to account for lower-bound and upper-bound censoring of the dependent variable. For the few

\footnotetext{
${ }^{26} \mathrm{~A}$ comparison between low and high wages shows a significantly larger labor supply when a high wage is paid only if gender discrimination is involved (EQLOw/EQHIGH, $p=0.72$; UNEQFAIR, $p=0.12$; UNEQUNFAIR, $p=0.20$; UNEQDISCR, $p<0.001$; two-sided $t$-tests). Non-parametric Mann-Whitney tests qualitatively lead to the same results. The implied wage elasticities of labor supply for our task are 0.02 in EQLOW/EQHIGH, 0.16 in UNEQFAIR, 0.11 in UNEQUNFAIR, and 0.36 in UNEQDISCR. Overall, these elasticities are in keeping with those estimated on online labor platforms. For instance, Dube et al. (2018) estimate the market-wide elasticity on Amazon Turk to be around 0.10 .
} 
Table 5: Tobit Regressions of Labor Supply on Payment Schemes

\begin{tabular}{|c|c|c|}
\hline \multirow[b]{2}{*}{ Scheme } & Low-Wage Workers & High-Wage Workers \\
\hline & $(1)$ & $(2)$ \\
\hline \multirow[t]{2}{*}{ UNEQFAIR } & -4.144 & -1.309 \\
\hline & $(4.337)$ & $(4.547)$ \\
\hline \multirow[t]{2}{*}{ UNEQUNFAIR } & -4.008 & -1.607 \\
\hline & $(4.115)$ & $(4.397)$ \\
\hline \multirow[t]{2}{*}{ UNEQDISCR } & $-13.610^{* * * *}$ & 1.146 \\
\hline & (4.051) & $(4.220)$ \\
\hline Controls & Yes & Yes \\
\hline Prob $>F$ & 0.001 & 0.010 \\
\hline Pseudo $R^{2}$ & 0.011 & 0.008 \\
\hline$N$ & 533 & 542 \\
\hline
\end{tabular}

Note: EQLOW/EQHigH serves as baseline. Standard errors are in parentheses. Two-sided $p$-values: ${ }^{*} p<0.10,{ }^{* *} p<0.05,{ }^{* * *} p<0.01$, ${ }^{* * * *} p<0.001$.

cases where the two techniques lead to different results in terms of statistical significance, we give priority to the non-parametric tests. ${ }^{27}$ Table 5 shows coefficient estimates of the Tobit regressions of labor supply on dummies for the payment schemes, separately for low-wage workers and high-wage workers. The payment schemes EQLOW and EQHIGH, respectively, serve as baselines.

To test Hypotheses 1 and 2, we start by testing the null hypothesis of equality of all schemes, and then conduct pairwise comparisons between the schemes using non-parametric Dunn's tests as well as the regression estimates. ${ }^{28}$ Both non-parametric Kruskal-Wallis (KW) tests and parametric Wald tests (on the restriction that the three scheme coefficients from the regression are jointly equal to zero) confirm that labor supply differs across the four schemes for lowwage workers, but not for high-wage workers (low-wage workers: $p=0.033 \mathrm{KW}, p=0.006$ Wald; high-wage workers: $p=0.825 \mathrm{KW}, p=0.901$ Wald; two-sided tests). For the pairwise comparisons, we use one-sided tests because our hypotheses are directional. Table 6 presents the $p$-values of the tests for the three main comparisons contained in each of the two hypotheses, with and without the Benjamini-Hochberg $(\mathrm{BH})$ correction for multiple hypothesis testing within each hypothesis. ${ }^{29}$

\footnotetext{
${ }^{27}$ We do so because non-parametric tests do not assume that error terms are normally distributed. For the Tobit regressions, we use robust standard errors because we find evidence of heteroscedasticity in our data. In the regressions, we also include control variables (age, gender, ethnicity, student status, employment status, experience on the platform, an index reflecting the percentage of approved participation in tasks on the platform, and day and time of participation).

${ }^{28}$ The Dunn's test (Dunn, 1964) allows us to conduct multiple pairwise comparisons, and is considered to be the correct test after a Kruskal-Wallis test. In the regressions, removing the controls does not change the results qualitatively.

${ }^{29}$ Table A1 in the Appendix presents the same for the six possible pairwise comparisons; the results are the same. The BH correction (Benjamini and Hochberg, 1995) is a common False Discovery Rate procedure, which controls for the probability of false positives among significant results. It differs from Family-wise Error Rate
} 
Table 6: $P$-values of Predicted Differences in Labor Supply between Payment Schemes

\begin{tabular}{|c|c|c|c|c|c|c|c|c|}
\hline \multirow[b]{2}{*}{ Predicted Inequality } & \multicolumn{4}{|c|}{ Low-Wage Workers } & \multicolumn{4}{|c|}{ High-Wage Workers } \\
\hline & (1) & (2) & (3) & (4) & (5) & (6) & (7) & $(8)$ \\
\hline Technique & Dunn & Tobit & Dunn & Tobit & Dunn & Tobit & Dunn & Tobit \\
\hline BH Correction & No & No & Yes & Yes & No & No & Yes & Yes \\
\hline $\begin{array}{c}\text { EQLOW/EQHIGH }> \\
\text { UNEQFAIR }\end{array}$ & 0.017 & 0.170 & 0.050 & 0.255 & 0.371 & 0.387 & 1.000 & 1.000 \\
\hline $\begin{array}{l}\text { UNEQFAIR > } \\
\text { UNEQUNFAIR }\end{array}$ & 0.878 & 0.513 & 0.878 & 0.513 & 0.780 & 0.473 & 1.000 & 0.709 \\
\hline $\begin{array}{l}\text { UNEQUNFAIR > } \\
\text { UNEQDISCR }\end{array}$ & 0.021 & 0.006 & 0.031 & 0.019 & 0.886 & 0.752 & 0.886 & 0.752 \\
\hline$N$ & 539 & 533 & 539 & 533 & 543 & 542 & 543 & 542 \\
\hline
\end{tabular}

Note: One-sided $p$-values in the direction predicted. BH corrections account for multiple hypothesis testing.

For low-wage workers, Table 6 shows that UNEQFAIR significantly decreases labor supply compared to EQLOW if we use non-parametric Dunn's tests, in line with Hypothesis 1. However, in contrast to this hypothesis, unfair chances have no additional negative effect, as labor supply in UNEQFAIR and UNEQUNFAIR are not significantly different. Finally, UNEQDISCR significantly reduces labor supply compared to UNEQUNFAIR, as predicted. ${ }^{30}$ The detected effects are also economically significant, which can be assessed using Table 4. Unfair chances due to gender discrimination decreases mean labor supply from 43.20 in EQLOW to 33.62 in UNEQDISCR, corresponding to a reduction of $22 \%$. Mean labor supply in UNEQUNFAIR is 39.22 , indicating that gender-discriminatory unfair chances reduce mean labor supply by $15 \%$ compared to unfair chances from an unspecified source. Moreover, mean labor supply in UNEQFAIR is 37.44 , representing a decrease of $13 \%$ compared to EQLOw. ${ }^{31}$

For high-wage workers, Table 6 reveals that none of the predicted inequalities in Hypothesis 2 hold. That is, high-wage workers provide similar labor supply across payment schemes. We summarize our first two results as follows.

\section{RESULT 1, LOW-WAGE WORKERS: (a) Gender-discriminating unfair chances (UNEQDISCR)} lower labor supply, compared to each other scheme. (b) Unfair chances from an unspecified source (UNEQUNFAIR) do not decrease labor supply compared to fair chances from an unspecified source (UNEQFAIR). (c) UNEQFAIR and UNEQUNFAIR reduce labor supply compared to EQLOW.

procedures such as Holm-Bonferroni (Holm, 1979), which control for the probability of at least one false positive among significant results.

${ }^{30}$ Table A1 in the Appendix shows that UNEQDISCR also reduces labor supply compared to EQLOW and UNEQUNFAIR. Moreover, UNEQUNFAIR reduces labor supply compared to EQLOW.

${ }^{31}$ In terms of pooled standard deviations, UNEQDISCR decreases labor supply by 0.35 standard deviations compared to EQLOW, and by 0.21 standard deviations compared to UNEQUNFAIR. The scheme UNEQFAIR reduces labor supply by 0.20 standard deviations relative to EQLOW. We estimate that our design can detect differences between schemes of approximately 0.20 standard deviations with medium statistical power $(\geq 50 \%)$. 
Result 2, High-WAge Workers: All payment schemes (UNEQDiscr, UnEQUnFAIR, UNEQFAIR, EQHIGH) produce similar labor supply.

Table 7: Tobit Regression of Labor Supply on Payment Schemes with Both Types of Workers

\begin{tabular}{|c|c|}
\hline Scheme & All Workers \\
\hline UNEQFAIR & $\begin{array}{l}-4.636 \\
(4.385)\end{array}$ \\
\hline UNEQUNFAIR & $\begin{array}{l}-4.432 \\
(4.098)\end{array}$ \\
\hline UNEQDISCR & $\begin{aligned}-13.133^{* * *} \\
(4.058)\end{aligned}$ \\
\hline UNEQFAIR $\times$ HighWage & $\begin{array}{c}2.030 \\
(6.318)\end{array}$ \\
\hline UNEQUNFAIR $\times$ HighWage & $\begin{array}{l}4.066 \\
(6.050)\end{array}$ \\
\hline UNEQDISCR $\times$ HighWage & $\begin{array}{c}13.307^{* *} \\
(5.790)\end{array}$ \\
\hline HighWage & $\begin{array}{c}2.291 \\
(4.352)\end{array}$ \\
\hline Controls & Yes \\
\hline Prob $>F$ & 0.000 \\
\hline Pseudo $R^{2}$ & 0.008 \\
\hline$N$ & 1075 \\
\hline \multicolumn{2}{|c|}{ Restriction I } \\
\hline \multicolumn{2}{|c|}{ UNEQUNFAIR $\times$ HighWage $=$ UNEQFAIR $\times$ HighWage } \\
\hline \multicolumn{2}{|c|}{ UNEQDISCR $\times$ HighWage $=$ UNEQUNFAIR $\times$ HighWage } \\
\hline \multicolumn{2}{|c|}{ Wald Test $($ two-sided $p$-value $)=0.073$} \\
\hline
\end{tabular}

We now turn to Hypothesis 3, which states that the labor supply decrease is larger for lowwage workers than for high-wage workers, when comparing the payment schemes UNEQFAIR with EqLow/EQHigh, UNEQUNFAIR with UNEQFAIR, and UNEQDisCR with UNEQUNFAIR, respectively. We evaluate the hypothesis with a Tobit regression using dummy variables for UNEQFAIR, UNEQUNFAIR, and UNEQDISCR as well as their interactions with a dummy variable for high-wage workers. We also include a set of controls that is common to both low-wage and high-wage workers. Table 7 presents the coefficient estimates. The overall null hypothesis, that there is no difference in labor supply between low-wage and high-wage workers in all payment scheme comparisons simultaneously, is represented by Restriction I at the bottom of the table. A Wald test marginally rejects this restriction (two-sided $p$-value $=$ $0.073) .{ }^{32}$

\footnotetext{
${ }^{32}$ Without controls, the $p$-value is 0.154 .
} 
Table 8: P-values of Predicted Differences in Labor Supply Effect of Payment Schemes between LowWage Workers and High-Wage Workers

\begin{tabular}{rcc}
\hline \hline & \multicolumn{3}{c}{ All Workers } \\
\cline { 2 - 3 } Predicted Inequality & $(1)$ & $(2)$ \\
Technique & Tobit & Tobit \\
BH Correction & No & Yes \\
\hline UNEQFAIR $\times$ HighWage $>0$ & 0.374 & 0.561 \\
UNEQUNFAIR $\times$ HighWage $>$ UNEQFAIR $\times$ HighWage & 0.503 & 0.503 \\
UNEQDISCR $\times$ HighWage $>$ UNEQUNFAIR $\times$ HighWage & 0.023 & 0.070 \\
\hline$N$ & 1075 & 1075 \\
\hline
\end{tabular}

Note: One-sided $p$-values are presented, in the direction predicted. BH corrections account for multiple hypothesis testing.

Table 8 presents $p$-values from Wald tests conducted separately for each of the three inequalities that compose Hypothesis 3. It shows that the decreases in labor supply caused by UNEQFAIR compared to EQLOW/EQHIGH and by UNEQUNFAIR compared to UNEQFAIR are not significantly larger for low-wage workers than for high-wage workers, rejecting the first and second inequality of the hypothesis. However, as predicted, the labor supply reduction caused by UNEQDISCR relative to UNEQUNFAIR is (marginally) significantly larger for lowwage workers. Overall, our analysis provides evidence only in favor of the discrimination part of Hypothesis 3. We state our third result as follows.

Result 3, Disadvantage vs. Advantage: (a) The decrease in labor supply caused by gender-discriminating unfair chances (UNEQDISCR) relative to unfair chances from an unspecified source (UNEQUNFAIR) is larger for low-wage workers than for high-wage workers. (b) The decreases caused by unfair chances from an unspecified source (UNEQUNFAIR) relative to fair chances from an unspecified source (UNEQFAIR) and by UNEQFAIR relative to EQLOW/EQHIGH are similar for both types of workers.

Finally, we evaluate whether low-wage men and women respond differently to genderdiscriminating unfair chances (UNEQDISCR) relative to unfair chances coming from an unspecified source (UNEQUNFAIR), as stated in Hypothesis 4. Table 9 presents descriptive statistics regarding labor supply for the two schemes, separately by gender. The right part of the table

Table 9: Labor Supply of Low-Wage Men and Women in UNEQUNFAIR and UNEQDisCR

\begin{tabular}{|c|c|c|c|c|c|c|c|c|c|c|}
\hline & \multicolumn{5}{|c|}{ Low-Wage Men } & \multicolumn{5}{|c|}{ Low-Wage Women } \\
\hline & Mean & SD & Min. & Max. & $N$ & Mean & $\mathrm{SD}$ & Min. & Max. & $N$ \\
\hline UNEQUNFAIR & 36.13 & 27.44 & .04 & .14 & 72 & 42.37 & 27.92 & .04 & .15 & 71 \\
\hline UNEQDISCR & 36.92 & 29.27 & .06 & .15 & 71 & 30.38 & 23.00 & .11 & .06 & 72 \\
\hline
\end{tabular}

Note: Labor supply is measured by the number of lines completed and ranges from 0 to 85 . Min. and Max. indicate the percentage of workers completing the minimum and maximum number of lines. 
shows that the mean labor supply of women differs considerably between the two schemes (42.37 in UNEQUNFAIR and 30.38 in UNEQDISCR; roughly 28\%). In contrast, as can be seen in the left part of the table, the mean labor supply of men is essentially equal in both schemes (36.13 in UNEQUNFAIR and 36.92 in UNEQDISCR).

Table 10: Tobit Regression of Labor Supply in UnEQUnfair and UNEQDiscr, for Low-Wage Men and Women

\begin{tabular}{rc}
\hline \hline Scheme & Low-Wage Workers \\
\hline UNEQDISCR & -1.363 \\
& $(5.510)$ \\
UNEQDISCR $\times$ Woman & $-16.105^{* *}$ \\
& $(7.805)$ \\
Woman & 1.736 \\
& $(6.077)$ \\
\hline Controls & Yes \\
Prob $>F$ & 0.039 \\
Pseudo $R^{2}$ & 0.012 \\
$N$ & 283 \\
\hline
\end{tabular}

Note: UNEQUNFAIR serves as baseline. Standard errors are indicated in parentheses. Two-sided $p$ values: ${ }^{*} p<0.10,{ }^{* *} p<0.05,{ }^{* * *} p<0.01,{ }^{* * * *} p<$ 0.001 .

Table 10 presents the estimates from a Tobit regression for low-wage workers in the two schemes with UNEQUNFAIR serving as the baseline, a dummy variable for women, and an interaction term of UNEQDISCR with the dummy variable for women. For men, discrimination does not significantly alter labor supply compared to unfair chances, as the coefficient of UNEQDISCR is insignificant ( $p=0.805$ ). However, the interaction term is negative and significant ( $p=0.040)$, indicating that the labor supply decrease caused by gender-discriminatory chances relative to the same unfair chances without gender discrimination is stronger for women than for men. ${ }^{33}$ Our fourth result is as follows.

Result 4, Gender and Negative Discrimination: The decrease in labor supply caused by UNEQDISCR relative to UNEQUNFAIR is greater for low-wage women than for low-wage men.

In summary, we find partial support for our hypotheses. In payment schemes involving chances to receive a low wage or a high wage, low-wage workers reduce labor supply relative to a scheme in which the low wage payment is the same for everyone. This effect is especially pronounced when chances are gender-discriminatory. Interestingly, there is no difference between fair and unfair chances when these come from an unspecified source. For high-wage

\footnotetext{
${ }^{33}$ The interaction term is also significant without controls $(p=0.043)$.
} 
workers, labor supply appears to be unaffected by the nature of the payment scheme. There is also partial evidence that the decrease in labor supply is stronger for low-wage workers than for high-wage workers, especially when gender-discriminatory chances are involved. Finally, women respond more strongly to gender-discriminatory chances than men do.

\section{VI.C. Exploratory Analyses}

Here we report some additional analyses that go beyond our pre-registered hypotheses. We first delve into other potential differences between genders and we then examine the effect of payment schemes on labor supply at the extensive and intensive margins.

Further Gender Differences. Figure 3 and Table 11 show descriptive statistics regarding the labor supply of workers in each payment scheme, separately for men and women. A comparison of the behavior of low-wage workers shows that the labor supply reactions to the different types of payment schemes differ considerably between genders. Men lower their labor supply in response to any of the three payment schemes with unequal wages, whereas women decrease their labor supply only in response to unequal wages resulting from gender-discriminatory chances.

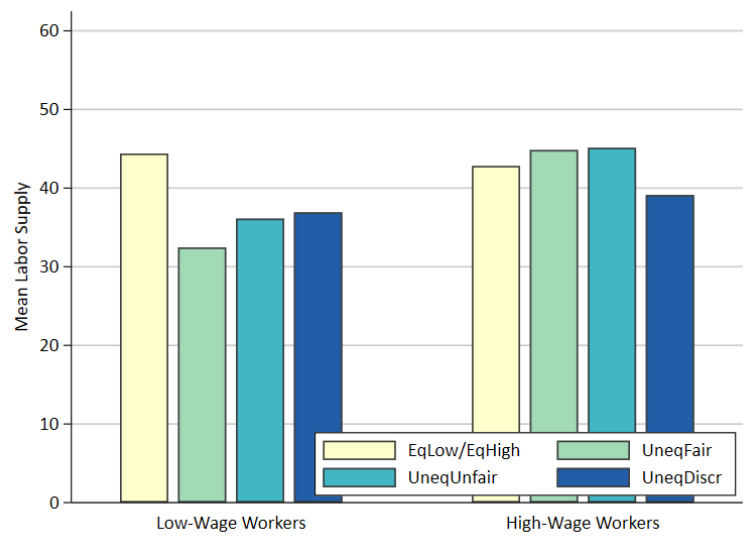

(a) Men

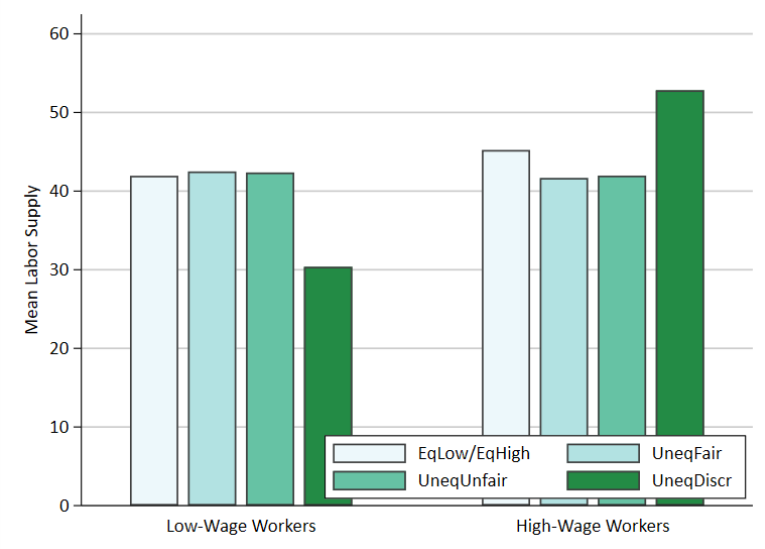

(b) Women

Figure 3: Mean Labor Supply per Gender and Payment Scheme

Note: Labor supply is measured by the number of lines completed and ranges from 0 to $85 . N$ ranges from 62 to 75 workers per payment scheme.

We test for differences in labor supply across payment schemes separately for men and women, using non-parametric Dunn's tests and Tobit regression estimates. ${ }^{34}$ Table 12 reports

\footnotetext{
${ }^{34}$ For the regression, we use the same specification as in Table 5, but include a dummy variable for women and interact this variable with the payment schemes. These Tobit regression estimates can be found in Table A2 of the Appendix.
} 
Table 11: Labor Supply per Gender and Payment Scheme

\begin{tabular}{|c|c|c|c|c|c|c|c|c|c|c|}
\hline & \multicolumn{5}{|c|}{ Low-Wage Workers } & \multicolumn{4}{|c|}{ High-Wage Workers } & \multirow[b]{2}{*}{$N$} \\
\hline & Mean & SD & Min. & Max. & $N$ & Mean & SD & Min. & Max. & \\
\hline Men & & & & & & & & & & \\
\hline EQLOW/EQHIGH & 44.40 & 27.20 & .02 & .18 & 65 & 42.83 & 27.95 & .06 & .16 & 64 \\
\hline UNEQFAIR & 32.46 & 28.70 & .10 & .13 & 63 & 44.85 & 29.35 & .03 & .19 & 62 \\
\hline UNEQUNFAIR & 36.13 & 27.44 & .04 & .14 & 72 & 45.13 & 30.05 & 01 & .23 & 69 \\
\hline UNEQDISCR & 36.92 & 29.27 & .06 & .15 & 71 & 39.12 & 25.08 & .04 & .09 & 75 \\
\hline Women & & & & & & & & & & \\
\hline EQLOW/EQHIGH & 41.95 & 28.24 & .06 & .14 & 63 & 45.23 & 30.05 & .02 & .25 & 64 \\
\hline UNEQFAIR & 42.50 & 28.97 & .03 & .21 & 62 & 41.68 & 30.05 & .03 & 20 & 65 \\
\hline UNEQUNFAIR & 42.37 & 27.92 & .04 & .15 & 71 & 41.97 & 27.80 & .03 & .16 & 74 \\
\hline UNEQDISCR & 30.38 & 23.00 & .11 & .06 & 72 & 52.83 & 26.77 & .03 & .23 & 70 \\
\hline
\end{tabular}

Note: Labor supply is measured by the number of lines completed and ranges from 0 to 85 . Min. and Max. indicate the percentage of workers completing the minimum and maximum number of lines.

the $p$-values of the tests for the three inequalities predicted by our first two hypotheses, now separately for men and for women. The tests corroborate the impression one has from looking at the descriptive statistics. Low-wage male workers significantly decrease their labor supply in UNEQFAIR compared to EQLOW, but do not further decrease labor supply in response to the additional inequalities contained in UNEQFAIR and UNEQDISCR. In contrast, low-wage female workers significantly decrease their labor supply only in UNEQDISCR relative to UNEQUNFAIR. Moreover, relative to EQLOW, low-wage men do significantly decrease their labor supply in reaction to any of the three types of inequalities ( $p$-values between 0.002 and 0.106 , depending on test and $\mathrm{BH}$ correction), whereas low-wage women significantly decrease their labor supply only when facing gender-discriminatory chances $(p \leq 0.009$ and $p \geq 0.548$ otherwise). In contrast, workers who receive a high wage do not significantly reduce their labor supply in response to the different payment schemes, irrespective of their gender. ${ }^{35}$

For high-wage female workers the descriptive statistics suggest an interesting pattern opposite to Hypothesis 2, namely an increase in labor supply in response to positive discrimination (see, e.g., Panel (b) of Figure 3). We compare UNEQDiscr and UnEQUnfair as well as UNEQDisCR and EQHIGH without imposing the predicted direction on our tests. We find that high-wage women in UNEQDISCR significantly increase their labor supply relative to UNEQUNFAIR ( $p \leq 0.038$, two-sided). The increase is also marginally significant relative to EQHigH if we use non-parametric tests $(p=0.055$, two-sided $) .{ }^{36}$

\footnotetext{
${ }^{35}$ More precisely, high-wage men reduce their labor supply in UNEQDISCR compared to UNEQFAIR, but only at marginally significant levels without the BH correction. For details on those comparisons, please see Table A3 in the Appendix.

${ }^{36}$ Table A4 in the Appendix reports $p$-values of comparisons and tests.
} 
Table 12: Tests of Inequalities in Labor Supply between Payment Schemes, for Men and Women

\begin{tabular}{|c|c|c|c|c|c|c|c|c|}
\hline \multirow[b]{2}{*}{ Predicted Inequality } & \multicolumn{4}{|c|}{ Low-Wage Workers } & \multicolumn{4}{|c|}{ High-Wage Workers } \\
\hline & (1) & (2) & (3) & (4) & (5) & (6) & $(7)$ & $(8)$ \\
\hline Technique & Dunn & Tobit & Dunn & Tobit & Dunn & Tobit & Dunn & Tobit \\
\hline $\mathrm{BH}$ Correction & No & No & Yes & Yes & No & No & Yes & Yes \\
\hline \multicolumn{9}{|l|}{ Men } \\
\hline $\begin{array}{c}\text { EQLOW/EQHIGH > } \\
\text { UNEQFAIR }\end{array}$ & 0.002 & 0.016 & 0.006 & 0.049 & 0.818 & 0.783 & 0.818 & 0.783 \\
\hline $\begin{array}{l}\text { UNEQFAIR > } \\
\text { UNEQUNFAIR }\end{array}$ & 0.920 & 0.716 & 0.920 & 0.716 & 0.248 & 0.508 & 0.372 & 0.762 \\
\hline $\begin{array}{l}\text { UNEQUNFAIR > } \\
\text { UNEQDISCR }\end{array}$ & 0.238 & 0.398 & 0.358 & 0.598 & 0.063 & 0.123 & 0.190 & 0.369 \\
\hline$N$ & 271 & 268 & 271 & 268 & 270 & 270 & 270 & 270 \\
\hline \multicolumn{9}{|l|}{ Women } \\
\hline $\begin{array}{l}\text { EQLOW/EQHIGH }> \\
\text { UNEQFAIR }\end{array}$ & 0.767 & 0.732 & 0.767 & 0.732 & 0.104 & 0.206 & 0.311 & 0.619 \\
\hline $\begin{array}{l}\text { UNEQFAIR > } \\
\text { UNEQUNFAIR }\end{array}$ & 0.751 & 0.305 & 1.000 & 0.457 & 0.801 & 0.517 & 1.000 & 0.775 \\
\hline $\begin{array}{l}\text { UNEQUNFAIR }> \\
\text { UNEQDISCR }\end{array}$ & 0.003 & 0.001 & 0.009 & 0.004 & 0.994 & 0.981 & 0.994 & 0.981 \\
\hline$N$ & 268 & 265 & 268 & 265 & 273 & 272 & 273 & 272 \\
\hline
\end{tabular}

Note: One-sided $p$-values are presented, in the direction predicted. $\mathrm{BH}$ corrections account for multiple hypothesis testing.

Extensive and Intensive Margins. To evaluate whether different payment schemes affect labor supply of low-wage workers at the extensive or the intensive margin, we use a two-equation hurdle model with a lower bound. We find that relative to UNEQUNFAIR, the scheme UNEQDISCR reduces both the probability that low-wage workers start to work at all ( $p=0.026$ without and $p=0.079$ with $\mathrm{BH}$ correction) and the labor supply of those who do decide to work ( $p=0.029$ without and $p=0.086$ with $\mathrm{BH}$ correction). The negative effect on labor supply of UNEQFAIR relative to the scheme EQLOW appears to affect only the intensive margin (intensive margin: $p=0.044$ without and $p=0.087$ with $\mathrm{BH}$ correction; extensive margin: $p \geq 0.228) .{ }^{37}$

\footnotetext{
${ }^{37} P$-values are one-sided in the predicted direction. Tables A5 and A6, respectively, show the results of the estimation and the $p$-values for the pairwise comparisons between payment schemes. In the Appendix we also provide further supplementary analyses. Tables A7-A10 detail labor supply reactions to the payment schemes for four additional demographic groups: the young and the old, and the full-time and part-time employed or unemployed. Furthermore, our pre-registered measure of labor supply is the number of lines, but other measures of labor supply are conceivable. Tables A11 and A12 show workers' responses to the different payment schemes if we use time spent in the experiment as the labor supply measure. Note that this measure does not only include time spent working on the task. As such, it is most likely not an appropriate measure of labor supply. Nevertheless, the results are very similar to our pre-registered measure. Lastly, for completeness, Tables A13 and A14 describe how the relatively few workers who beat the odds respond to the different payment schemes.
} 


\section{Discussion}

\section{VII.A. Unequal Wages and Labor Supply}

Bracha et al. (2015), Breza et al. (2018), and Dube et al. (2019) (henceforth BGL, BKS, and $D G L$ ) study the effect of unequal wages on labor supply, but do not investigate the role of chances and discrimination. $B G L$ conduct a laboratory experiment, $B K S$ employ a field experiment, and $D G L$ exploit a natural experiment. Here, we briefly compare our results concerning unequal wages resulting from fair chances or unfair chances with an unspecified source (that is, UNEQFAIR or UNEQUNFAIR) to the results of these three studies. ${ }^{38}$

In line with these three studies, we obtain the result that unequal wages significantly decrease labor supply of low-wage workers. In addition, our finding that unequal wages do not affect labor supply of high-wage workers is also found by $B G L$ and $D G L$, although $B K S$ report evidence that such workers may reduce their labor supply. Furthermore, regarding gender differences, we find that only low-wage men negatively respond to wage differences, whereas women do not. This is consistent with the result reported in $B G L$ that only men respond to wage inequality. ${ }^{39}$

Thus, our findings corroborate the existing results on the negative labor supply effects of wage inequality and add evidence that this may be mainly driven by low-wage men.

\section{VII.B. Fairness of Chances}

One motivation of our research is to explore how the (un)fairness of initial chances between two workers affects their labor supply decisions once wages are known. To the best of our knowledge, no other study investigates this question. However, a number of scholars have analyzed the effect of ex ante fairness more generally. Closest to our research are the studies examining whether and how fairness of ex ante chances between individuals influences their equity judgments.

Starting with Diamond (1967), many have argued that an unequal outcome is more acceptable if it is generated by fair chances than if it is generated by unfair chances (see Section II.B). However, there may be a tension between ex ante and ex post fairness (e.g., Myerson, 1981; Fudenberg and Levine, 2012; Saito, 2013). Nevertheless, experimental studies have shown that individuals are more likely to accept an unequal outcome that results from fair chances than

\footnotetext{
${ }^{38} B G L$ and $B K S$ also consider cases where unequal wages may be justified, e.g., by productivity differences. We do not discuss these results.

${ }^{39} B K S$ only sample men and $D G L$ do not report effects by gender. There are also other demographic differences between the four studies. For instance, $B G L$ employ American university students, $D G L$ use young American part-time workers, and $B K S$ use Indian temporary workers who may be older. We use online UK workers with a median age of 36 , most of whom are either full-time or part-time employed.
} 
one that results from unfair chances (e.g., Bolton et al., 2005; Grimalda et al., 2016). In stark contrast, we find that behavior of workers is insensitive to initial chances when they are generated by an unspecified source, as labor supply is almost identical under the payment schemes UNEQFAIR and UNEQUNFAIR. ${ }^{40}$ However, workers in our study do respond to unfair chances coming from gender discrimination, a prominent form of procedural unfairness. This complements findings that workers' reaction to unequal wages depends on the reason behind wage inequality (e.g., workers may accept or even demand wage inequality if it reflects productivity differences, Abeler et al., 2010; Breza et al., 2018, or if some other justification is provided, Bracha et al., 2015).

Our research carries a potential implication for managerial policy. Managers might be tempted to believe that offering initially fair chances will mitigate the negative effects of unequal wages in bonus or promotion schemes. However, our results suggest that, ceteris paribus, unequal wages resulting from fair chances will still exert a detrimental effect on disadvantaged workers' labor supply.

\section{VII.C. Discrimination, Labor Supply, and the Gender Gap in Earnings}

Goldin (2014) and Blau and Kahn (2017) report that the most important determinant of the modern gender earnings gap is that women exhibit lower labor supply. Women are less present in high-pay occupations, which usually demand long working hours (e.g., lawyer, manager, professor), and women work less and earn less within the same occupation, which typically offer rapidly-rising returns to working hours. The main explanation for the lower labor supply put forward in the literature is that women prefer temporal flexibility at work, notably working less hours, because they have to bear a much greater share of household responsibilities (e.g., Bertrand et al., 2010; Flabbi and Moro, 2012; Goldin, 2014; Goldin and Katz, 2016; Wiswall and Zafar, 2017; Cortés and Pan, 2019). ${ }^{41}$

Our result that women decrease their labor supply in response to gender-discriminatory chances offers a complementary explanation for women's lower labor supply and lower earnings. Consider the following example. A young female lawyer starts at a law firm, and is as willing as anyone to work extra hours. The older partners promote similar young male lawyers

\footnotetext{
${ }^{40}$ We note that, as in the aforementioned experiments, in UNEQFAIR and UNEQUNFAIR chances are assigned without a specific reason.

${ }^{41}$ In a recent field experiment Mas and Pallais (2017) find that women indeed have greater preference for temporal flexibility, but that this is not enough to explain the gender earnings gap. There is evidence supporting other explanations for the modern gender earnings gap, including discrimination (e.g., Neumark et al., 1996; Goldin and Rouse, 2000; Reuben et al., 2014; Sarsons et al., 2019), differences in bargaining behavior and competitiveness (e.g., Niederle and Vesterlund, 2007; Buser et al., 2014; Card et al., 2015), differences in productivity (e.g., Mulligan and Rubinstein, 2008), social norms (e.g., Coffman, 2014; Bertrand et al., 2015; Bursztyn et al., 2017), and stereotypes (e.g., Bordalo et al., 2019).
} 
in her place because they wrongly believe that, being a woman, she will be less willing to work extra hours. Our result then suggests that, unsatisfied at being discriminated, she chooses not to work extra hours whenever she can, thereby decreasing her value to the firm. Observing her behavior over time, the older partners are comforted in their initial choice, because their (formerly wrong) belief is now confirmed. Thus, the discrimination that women experience in labor markets may decrease their willingness to enter potential high-income occupations and may also reduce their willingness to work long hours for a given salary within an occupation. In this case, the effect of discrimination on labor supply can become a self-fulfilling prophecy, and breaking this cycle may therefore prove to be no small feat.

Our result that gender-based unfair chances reduce female labor supply also challenges a commonly made assumption in the estimation of discrimination. Discrimination is regularly estimated by measuring the difference in earnings between men and women with the same characteristics - e.g., age, education, experience, hours worked and occupation —under the assumption that these characteristics are themselves unaffected by discrimination (see Oaxaca, 1973; Blinder, 1973, and Fortin et al., 2011 for an overview of the method). However, finding that men earn higher wages because they work longer hours - and that, hence, men and women would earn similar wages if they worked the same hours - can hide that women work less hours (and incur disutility) exactly because of discrimination (see our argument above). That is, the impact of gender discrimination is likely underestimated.

Finally, our data also provide suggestive evidence that positive gender discrimination may increase labor supply of women. Specifically, the labor supply of women is greater under unequal high wages with positive discrimination of women (UNEQDISCR) than under unequal high wages with unfair chances from an unspecified source (UNEQFAIR) and than under equal high wages (EQHigH). This is consistent with a few studies finding beneficial effects of positive discrimination in other settings (Balafoutas and Sutter, 2012; Niederle et al., 2013; Ibañez and Riener, 2018), even though our study controls for monetary incentives. However, we are careful in drawing definite conclusions on this matter and leave this important question for future research.

\section{VII.D. Possible Extensions}

We have chosen an experiment design that allows us to explore the effects of unfair chances and gender discrimination in the cleanest possible way. Naturally, several extensions are conceivable to account for features of labor decisions that are not part of our design. The following four extensions appear particularly interesting. First, since employers often cannot fully contract effort, and it has been shown that employees tend to reciprocate higher wages with higher 
effort (e.g., Fehr et al., 1993, 1998), one could study how the presence of discrimination affects reciprocal effort. It is conceivable that the possibility of gift-exchange-giving workers the possibility to negatively (positively) respond to an employer who negatively (positively) discriminates - by changing work effort will reveal even greater effects of discrimination on work behavior than those observed in our setting of complete contracts. Second, one could augment our design to account for team production, and study how discrimination impacts the ability of teams to cooperate, coordinate, and produce. In such a setting discrimination may generate negative external effects on non-discriminated workers. Third, since promotion chances often take the form of multi-period tournaments where effort influences chances of promotion (e.g., Lazear and Rosen, 1981), one could study the effect of discrimination on labor supply in a more complex tournament-style design. Fourth, it may be interesting to study whether other common forms of discrimination, such as ethnic discrimination, generate similar effects as those we find for gender.

\section{Conclusion}

We provide the first causal evidence regarding how unfair chances to receive a low or high wage - stemming from an unspecified source of from gender discrimination-affect labor supply decisions. We find that, at a given wage, explicit gender discrimination in chances considerably reduces the labor supply of disadvantaged workers compared to an equal-wage setting $(-22 \%)$. This is the case even though workers only hurt themselves by working less. Moreover, low wages stemming from gender-discriminatory chances reduce labor supply almost twice as much as low wages resulting from fair chances $(-13 \%)$. Interestingly, in the absence of discrimination, low-wage workers are insensitive to whether unequal wages result from fair or unfair chances. Advantaged workers are unresponsive to any type of inequality that we examine.

Moreover, we find suggestive evidence that men and women respond differently to unfair chances and discrimination. Men reduce their labor supply when they are in a disadvantaged wage position, irrespective of the reason behind the disadvantage, whereas women decrease their labor supply only when their low wage can be attributed to gender-based discrimination in chances.

Our findings provide a novel supply-side effect of gender discrimination in labor markets, and offer a complementary way to account for the lower supply of women and the gender gap in earnings. More broadly, our study opens new avenues for research on the reactions of workers who face discrimination. 


\section{References}

Abeler, J., Altmann, S., Kube, S., and Wibral, M. (2010). Gift exchange and workers' fairness concerns: when equality is unfair. Journal of the European Economic Association, 8(6):1299-1324.

Adams, J. S. (1965). Inequity in social exchange. In Berkowitz, L., editor, Advances in Experimental Social Psychology, volume 2, pages 267-299. Academic Press, New York and London.

Akerlof, G. A. and Yellen, J. L. (1990). The fair wage-effort hypothesis and unemployment. Quarterly Journal of Economics, 105(2):255-283.

Altonji, J. G. and Blank, R. M. (1999). Race and gender in the labor market. In Ashenfelter, O. C. and Card, D., editors, Handbook of Labor Economics, volume 3c, chapter 48, pages 3143-3259. North Holland, Amsterdam.

Andreoni, J., Aydin, D., Barton, B., Bernheim, B. D., and Naecker, J. (2016). When fair isn't fair: sophisticated time inconsistency in social preferences. Working Paper.

Arechar, A. A., Gächter, S., and Molleman, L. (2018). Conducting interactive experiments online. Experimental Economics, 21(1):99-131.

Arrow, K. (1973). The theory of discrimination. In Ashenfelter, O. and Rees, A., editors, Discrimination in Labor Markets, pages 3-33. Princeton University Press, Princeton.

Balafoutas, L. and Sutter, M. (2012). Affirmative action policies promote women and do not harm efficiency in the laboratory. Science, 335(6068):579-582.

Bartoš, V., Bauer, M., Chytilová, J., and Matějka, F. (2016). Attention discrimination: theory and field experiments with monitoring information acquisition. American Economic Review, 106(6):1437-75.

Becker, G. S. (1971). The Economics of Discrimination. University of Chicago Press, Chicago.

Benjamini, Y. and Hochberg, Y. (1995). Controlling the false discovery rate: a practical and powerful approach to multiple testing. Journal of the Royal Statistical Society Series B (Methodological), pages 289-300.

Bertrand, M., Chugh, D., and Mullainathan, S. (2005). Implicit discrimination. American Economic Review, 95(2):94-98. 
Bertrand, M. and Duflo, E. (2017). Field experiments on discrimination. In Duflo, E. and Banerjee, A., editors, Handbook of Economic Field Experiments, volume 1, chapter 8, pages 309-393. North Holland, Amsterdam.

Bertrand, M., Goldin, C., and Katz, L. F. (2010). Dynamics of the gender gap for young professionals in the financial and corporate sectors. American Economic Journal: Applied Economics, 2(3):228-255.

Bertrand, M., Kamenica, E., and Pan, J. (2015). Gender identity and relative income within households. Quarterly Journal of Economics, 130(2):571-614.

Bewley, T. (1999). Why Don't Wages Fall in a Recession. Harvard University Press, Cambridge.

Blau, F. D. and Kahn, L. M. (2017). The gender wage gap: extent, trends, and explanations. Journal of Economic Literature, 55(3):789-865.

Blinder, A. S. (1973). Wage discrimination: reduced form and structural estimates. Journal of Human Resources, 8(4):436-455.

Bohren, J. A., Imas, A., and Rosenberg, M. (2018). The dynamics of discrimination: Theory and evidence. PIER Working Paper (18-016).

Bolton, G. E., Brandts, J., and Ockenfels, A. (2005). Fair procedures: Evidence from games involving lotteries. Economic Journal, 115(506):1054-1076.

Bordalo, P., Coffman, K., Gennaioli, N., and Shleifer, A. (2016). Stereotypes. Quarterly Journal of Economics, 131(4):1753-1794.

Bordalo, P., Coffman, K., Gennaioli, N., and Shleifer, A. (2019). Beliefs about gender. American Economic Review, 109(3):739-73.

Bracha, A., Gneezy, U., and Loewenstein, G. (2015). Relative pay and labor supply. Journal of Labor Economics, 33(2):297-315.

Breza, E., Kaur, S., and Shamdasani, Y. (2018). The morale effects of pay inequality. Quarterly Journal of Economics, 133(2):611-663.

Brock, J. M., Lange, A., and Ozbay, E. Y. (2013). Dictating the risk: Experimental evidence on giving in risky environments. American Economic Review, 103(1):415-37. 
Bursztyn, L., Fujiwara, T., and Pallais, A. (2017). 'Acting wife': marriage market incentives and labor market investments. American Economic Review, 107(11):3288-3319.

Buser, T., Niederle, M., and Oosterbeek, H. (2014). Gender, competitiveness, and career choices. Quarterly Journal of Economics, 129(3):1409-1447.

Cappelen, A. W., Konow, J., Sørensen, E. Ø., and Tungodden, B. (2013). Just luck: An experimental study of risk-taking and fairness. American Economic Review, 103(4):1398-1413.

Card, D., Cardoso, A. R., and Kline, P. (2015). Bargaining, sorting, and the gender wage gap: quantifying the impact of firms on the relative pay of women. Quarterly Journal of Economics, 131(2):633-686.

Card, D., Mas, A., Moretti, E., and Saez, E. (2012). Inequality at work: the effect of peer salaries on job satisfaction. American Economic Review, 102(6):2981-3003.

Cettolin, E. and Riedl, A. (2016). Justice under uncertainty. Management Science, 63(11):3739-3759.

Charness, G. and Kuhn, P. (2007). Does pay inequality affect worker effort? Experimental evidence. Journal of Labor Economics, 25(4):693-723.

Chen, Y. and Konstan, J. (2015). Online field experiments: a selective survey of methods. Journal of the Economic Science Association, 1(1):29-42.

Coffman, K. B. (2014). Evidence on self-stereotyping and the contribution of ideas. Quarterly Journal of Economics, 129(4):1625-1660.

Coffman, K. B., Coffman, L. C., and Ericson, K. M. M. (2016). The size of the LGBT population and the magnitude of antigay sentiment are substantially underestimated. Management Science, 63(10):3168-3186.

Coffman, K. B., Exley, C. L., and Niederle, M. (2017). When gender discrimination is not about gender. Harvard Business School Working Paper.

Cohn, A., Fehr, E., Herrmann, B., and Schneider, F. (2014). Social comparison and effort provision: evidence from a field experiment. Journal of the European Economic Association, 12(4):877-898.

Cortés, P. and Pan, J. (2019). When time binds: substitutes for household production, returns to working long hours, and the skilled gender wage gap. Journal of Labor Economics, 37(2):351-398. 
Croson, R. and Gneezy, U. (2009). Gender differences in preferences. Journal of Economic Literature, 47(2):448-74.

De Quidt, J., Haushofer, J., and Roth, C. (2018). Measuring and bounding experimenter demand. American Economic Review, 108(11):3266-3302.

Diamond, P. A. (1967). Cardinal welfare, individualistic ethics, and interpersonal comparison of utility: comment. Journal of Political Economy, 75(5):765.

Dube, A., Giuliano, L., and Leonard, J. (2019). Fairness and frictions: the impact of unequal raises on quit behavior. American Economic Review, 109(2):620-63.

Dube, A., Jacobs, J., Naidu, S., and Suri, S. (2018). Monopsony in online labor markets. NBER Working Paper (w24416).

Dunn, O. J. (1964). Multiple comparisons using rank sums. Technometrics, 6(3):241-252.

Epstein, L. G. and Segal, U. (1992). Quadratic social welfare functions. Journal of Political Economy, 100(4):691-712.

Fehr, E., Kirchsteiger, G., and Riedl, A. (1993). Does fairness prevent market clearing? An experimental investigation. Quarterly Journal of Economics, 108(2):437-459.

Fehr, E., Kirchsteiger, G., and Riedl, A. (1998). Gift exchange and reciprocity in competitive experimental markets. European Economic Review, 42(1):1-34.

Fehr, E. and Schmidt, K. M. (1999). A theory of fairness, competition, and cooperation. Quarterly Journal of Economics, 114(3):817-868.

Flabbi, L. and Moro, A. (2012). The effect of job flexibility on female labor market outcomes: estimates from a search and bargaining model. Journal of Econometrics, 168(1):81-95.

Fleurbaey, M. (2010). Assessing risky social situations. Journal of Political Economy, 118:649-680.

Fortin, N., Lemieux, T., and Firpo, S. (2011). Decomposition methods in economics. In Ashenfelter, O. C. and Card, D., editors, Handbook of Labor Economics, volume 4a, chapter 1, pages 1-102. North Holland, Amsterdam.

Fréchette, G. R. (2012). Session-effects in the laboratory. Experimental Economics, 15(3):485498. 
Fudenberg, D. and Levine, D. K. (2012). Fairness, risk preferences and independence: Impossibility theorems. Journal of Economic Behavior and Organization, 81(2):606-612.

Gächter, S. and Thöni, C. (2010). Social comparison and performance: experimental evidence on the fair wage-effort hypothesis. Journal of Economic Behavior \& Organization, 76(3):531-543.

Ghani, E., Kerr, W. R., and Stanton, C. (2014). Diasporas and outsourcing: evidence from odesk and india. Management Science, 60(7):1677-1697.

Gilchrist, D. S., Luca, M., and Malhotra, D. (2016). When $3+1>4$ : gift structure and reciprocity in the field. Management Science, 62(9):2639-2650.

Glover, D., Pallais, A., and Pariente, W. (2017). Discrimination as a self-fulfilling prophecy: evidence from french grocery stores. Quarterly Journal of Economics, 132(3):1219-1260.

Goldin, C. (2014). A grand gender convergence: its last chapter. American Economic Review, 104(4):1091-1119.

Goldin, C. and Katz, L. F. (2016). A most egalitarian profession: pharmacy and the evolution of a family-friendly occupation. Journal of Labor Economics, 34(3):705-746.

Goldin, C. and Rouse, C. (2000). Orchestrating impartiality: the impact of "blind" auditions on female musicians. American Economic Review, 90(4):715-741.

Grimalda, G., Kar, A., and Proto, E. (2016). Procedural fairness in lotteries assigning initial roles in a dynamic setting. Experimental Economics, 19(4):819-841.

Hammond, P. J. (1981). Ex-ante and ex-post welfare optimality under uncertainty. Economica, 48(191):235-250.

Harsanyi, J. C. (1955). Cardinal welfare, individualistic ethics, and interpersonal comparisons of utility. Journal of Political Economy, 63(4):309-321.

Holm, S. (1979). A simple sequentially rejective multiple test procedure. Scandinavian Journal of Statistics, 6(2):65-70.

Horton, J. J. (2017a). The effects of algorithmic labor market recommendations: evidence from a field experiment. Journal of Labor Economics, 35(2):345-385.

Horton, J. J. (2017b). Price floors and employer preferences: Evidence from a minimum wage experiment. CESifo Working Paper (6548). 
Horton, J. J., Rand, D. G., and Zeckhauser, R. J. (2011). The online laboratory: conducting experiments in a real labor market. Experimental Economics, 14(3):399-425.

Ibañez, M. and Riener, G. (2018). Sorting through affirmative action: three field experiments in Colombia. Journal of Labor Economics, 36(2):437-478.

Karni, E. and Safra, Z. (2002). Individual sense of justice: a utility representation. Econometrica, 70(1):263-284.

Karni, E., Salmon, T., and Sopher, B. (2008). Individual sense of fairness: an experimental study. Experimental Economics, 11(2):174-189.

Konow, J. (2000). Fair shares: Accountability and cognitive dissonance in allocation decisions. American Economic Review, 90(4):1072-1091.

Krawczyk, M. (2010). A glimpse through the veil of ignorance: equality of opportunity and support for redistribution. Journal of Public Economics, 94(1-2):131-141.

Krawczyk, M. (2011). A model of procedural and distributive fairness. Theory and Decision, 70(1):111-128.

Krawczyk, M. and Le Lec, F. (2010). 'Give me a chance!' An experiment in social decision under risk. Experimental Economics, 13(4):500-511.

Kuziemko, I., Norton, M. I., Saez, E., and Stantcheva, S. (2015). How elastic are preferences for redistribution? Evidence from randomized survey experiments. American Economic Review, 105(4):1478-1508.

Lang, K. (1986). A language theory of discrimination. Quarterly Journal of Economics, 101(2):363-382.

Lazear, E. P. and Rosen, S. (1981). Rank-order tournaments as optimum labor contracts. Journal of Political Economy, 89(5):841-864.

Leventhal, G. S., Karuza, J., and Fry, W. R. (1980). Beyond fairness: a theory of allocation preferences. Justice and Social Interaction, 3(1):167-218.

Mas, A. and Pallais, A. (2017). Valuing alternative work arrangements. American Economic Review, 107(12):3722-59.

Miao, B. and Zhong, S. (2018). Probabilistic social preference: how Machina's Mom randomizes her choice. Economic Theory, 65(1):1-24. 
Mulligan, C. B. and Rubinstein, Y. (2008). Selection, investment, and women's relative wages over time. Quarterly Journal of Economics, 123(3):1061-1110.

Myerson, R. B. (1981). Utilitarianism, egalitarianism, and the timing effect in social choice problems. Econometrica, 49(4):883-897.

Neumark, D., Bank, R. J., and Van Nort, K. D. (1996). Sex discrimination in restaurant hiring: an audit study. Quarterly Journal of Economics, 111(3):915-941.

Niederle, M. (2016). Gender. In Kagel, J. H. and Roth, A. E., editors, Handbook of Experimental Economics, volume 2, chapter 8, pages 481-562. Princeton University Press, Princeton and Oxford.

Niederle, M., Segal, C., and Vesterlund, L. (2013). How costly is diversity? Affirmative action in light of gender differences in competitiveness. Management Science, 59(1):1-16.

Niederle, M. and Vesterlund, L. (2007). Do women shy away from competition? Do men compete too much? Quarterly Journal of Economics, 122(3):1067-1101.

Oaxaca, R. (1973). Male-female wage differentials in urban labor markets. International Economic Review, 14(3):693-709.

Ockenfels, A., Sliwka, D., and Werner, P. (2014). Bonus payments and reference point violations. Management Science, 61(7):1496-1513.

Pallais, A. (2014). Inefficient hiring in entry-level labor markets. American Economic Review, 104(11):3565-99.

Pallais, A. and Sands, E. G. (2016). Why the referential treatment? Evidence from field experiments on referrals. Journal of Political Economy, 124(6):1793-1828.

Parsons, C. A., Sulaeman, J., Yates, M. C., and Hamermesh, D. S. (2011). Strike three: discrimination, incentives, and evaluation. American Economic Review, 101(4):1410-35.

Pascoe, E. A. and Smart Richman, L. (2009). Perceived discrimination and health: a metaanalytic review. Psychological Bulletin, 135(4):531.

Pfeffer, J. and Langton, N. (1993). The effect of wage dispersion on satisfaction, productivity, and working collaboratively: evidence from college and university faculty. Administrative Science Quarterly, 38(3):382-407. 
Phelps, E. S. (1972). The statistical theory of racism and sexism. American Economic Review, 62(4):659-661.

Reuben, E., Sapienza, P., and Zingales, L. (2014). How stereotypes impair womens careers in science. Proceedings of the National Academy of Sciences, 111(12):4403-4408.

Riach, P. A. and Rich, J. (2002). Field experiments of discrimination in the market place. Economic Journal, 112(483):F480-F518.

Saito, K. (2013). Social preferences under risk: Equality of opportunity versus equality of outcome. American Economic Review, 103(7):3084-3101.

Sarsons, H., Gërxhani, K., Reuben, E., and Schram, A. (2019). Gender differences in recognition for group work. Working Paper.

Skarlicki, D. P. and Folger, R. (1997). Retaliation in the workplace: the roles of distributive, procedural, and interactional justice. Journal of Applied Psychology, 82(3):434.

Snowberg, E. and Yariv, L. (2018). Testing the waters: Behavior across participant pools. NBER Working Paper (24781).

Stanton, C. T. and Thomas, C. (2015). Landing the first job: the value of intermediaries in online hiring. Review of Economic Studies, 83(2):810-854.

Trautmann, S. T. (2009). A tractable model of process fairness under risk. Journal of Economic Psychology, 30(5):803-813.

Trautmann, S. T. and van de Kuilen, G. (2016). Process fairness, outcome fairness, and dynamic consistency: Experimental evidence for risk and ambiguity. Journal of Risk and Uncertainty, 53(2-3):75-88.

Wiswall, M. and Zafar, B. (2017). Preference for the workplace, investment in human capital, and gender. Quarterly Journal of Economics, 133(1):457-507. 


\section{Appendix}

We provide additional figures and tables in Section A and the instructions of the experiment as seen by the workers in Section B. Each figure and table is referred to in the main text by its number.

\section{A. Additional Figures and Tables}

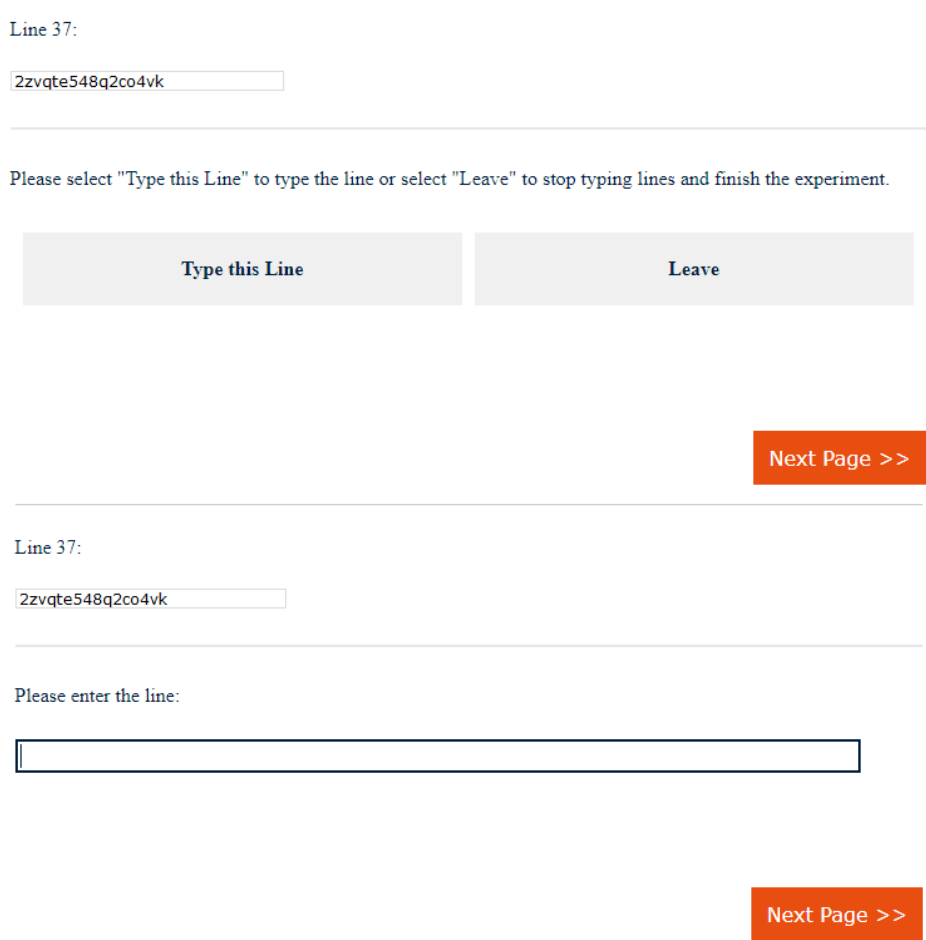

Figure A1: Task

Note: In the upper screenshot, the worker sees a line of characters, and decides whether to type the line or to leave the experiment. In the lower screenshot, if choosing not to leave, the worker is required to enter the line. 
Table A1: $P$-Values of Six Predicted Differences in Labor Supply between Payment Schemes

\begin{tabular}{|c|c|c|c|c|c|c|c|c|}
\hline \multirow[b]{2}{*}{ Predicted Inequality } & \multicolumn{4}{|c|}{ Low-Wage Workers } & \multicolumn{4}{|c|}{ High-Wage Workers } \\
\hline & (1) & (2) & (3) & (4) & (5) & (6) & (7) & $(8)$ \\
\hline Technique & Dunn & Tobit & Dunn & Tobit & Dunn & Tobit & Dunn & Tobit \\
\hline BH Correction & No & No & Yes & Yes & No & No & Yes & Yes \\
\hline $\begin{array}{c}\text { EQLOW/EQHIGH }> \\
\text { UNEOFAIR }\end{array}$ & 0.017 & 0.170 & 0.050 & 0.212 & 0.371 & 0.387 & 1.000 & 1.000 \\
\hline $\begin{array}{l}\text { EQLOW/EQHIGH }> \\
\text { UNEQUNFAIR }\end{array}$ & 0.058 & 0.165 & 0.087 & 0.248 & 0.426 & 0.357 & 1.000 & 1.000 \\
\hline $\begin{array}{l}\text { EQLOW/EQHIGH }> \\
\text { UNEQDISCR }\end{array}$ & 0.001 & 0.001 & 0.006 & 0.002 & 0.853 & 0.607 & 1.000 & 0.910 \\
\hline $\begin{array}{l}\text { UNEQFAIR > } \\
\text { UNEQUNFAIR }\end{array}$ & 0.878 & 0.513 & 0.878 & 0.513 & 0.780 & 0.473 & 1.000 & 0.946 \\
\hline $\begin{array}{l}\text { UNEQFAIR > } \\
\text { UNEQDISCR }\end{array}$ & 0.081 & 0.013 & 0.102 & 0.025 & 0.905 & 0.720 & 0.905 & 0.900 \\
\hline $\begin{array}{l}\text { UNEQUNFAIR > } \\
\text { UNEQDISCR }\end{array}$ & 0.021 & 0.006 & 0.031 & 0.019 & 0.886 & 0.752 & 1.000 & 0.752 \\
\hline$N$ & 539 & 533 & 539 & 533 & 543 & 542 & 543 & 542 \\
\hline
\end{tabular}

Note: One-sided $p$-values are presented, in the direction predicted. BH corrections account for multiple hypothesis testing. 
Table A2: Tobit Regression of Labor Supply on Payment Schemes, for Men and Women

\begin{tabular}{|c|c|c|c|c|c|c|}
\hline & \multicolumn{3}{|c|}{ Low-Wage Workers } & \multicolumn{3}{|c|}{ High-Wage Workers } \\
\hline & Men & Women & $\begin{array}{l}\text { Men \& } \\
\text { Women }\end{array}$ & Men & Women & $\begin{array}{l}\text { Men \& } \\
\text { Women }\end{array}$ \\
\hline Scheme & (1) & (2) & (3) & (4) & (5) & $(6)$ \\
\hline UNEQFAIR & $\begin{array}{c}-12.788^{* *} \\
(5.950)\end{array}$ & $\begin{array}{c}3.919 \\
(6.311)\end{array}$ & $\begin{array}{c}-12.682^{* *} \\
(5.909)\end{array}$ & $\begin{array}{c}4.947 \\
(6.307)\end{array}$ & $\begin{array}{l}-5.478 \\
(6.674)\end{array}$ & $\begin{array}{c}3.238 \\
(6.351)\end{array}$ \\
\hline UNEQUNFAIR & $\begin{array}{c}-9.366^{*} \\
(5.585)\end{array}$ & $\begin{array}{c}0.715 \\
(5.938)\end{array}$ & $\begin{array}{c}-8.896 \\
(5.669)\end{array}$ & $\begin{array}{c}5.069 \\
(6.368)\end{array}$ & $\begin{array}{l}-5.213 \\
(6.347)\end{array}$ & $\begin{array}{c}3.342 \\
(6.273)\end{array}$ \\
\hline UNEQDISCR & $\begin{array}{c}-10.802^{*} \\
(5.952)\end{array}$ & $\begin{array}{c}-15.378^{* * *} \\
(5.561)\end{array}$ & $\begin{array}{c}-11.092^{*} \\
(5.831)\end{array}$ & $\begin{array}{l}-1.698 \\
(5.640)\end{array}$ & $\begin{array}{c}7.046 \\
(6.390)\end{array}$ & $\begin{array}{l}-3.679 \\
(5.649)\end{array}$ \\
\hline UNEQFAIR $\times$ Woman & & & $\begin{array}{c}17.242^{* *} \\
(8.605)\end{array}$ & & & $\begin{array}{l}-8.769 \\
(9.269)\end{array}$ \\
\hline UNEQUNFAIR $\times$ Woman & & & $\begin{array}{c}9.878 \\
(8.163)\end{array}$ & & & $\begin{array}{l}-9.287 \\
(8.848)\end{array}$ \\
\hline UNEQDISCR $\times$ Woman & & & $\begin{array}{l}-5.021 \\
(7.966)\end{array}$ & & & $\begin{array}{l}10.430 \\
(8.533)\end{array}$ \\
\hline Woman & & & $\begin{array}{l}-5.400 \\
(6.212)\end{array}$ & & & $\begin{array}{c}5.317 \\
(6.854)\end{array}$ \\
\hline Controls & Yes & Yes & Yes & Yes & Yes & Yes \\
\hline Prob $>F$ & 0.053 & 0.000 & 0.000 & 0.045 & 0.000 & 0.003 \\
\hline Pseudo $R^{2}$ & 0.014 & 0.019 & 0.013 & 0.013 & 0.010 & 0.010 \\
\hline$N$ & 268 & 265 & 542 & 270 & 272 & 542 \\
\hline
\end{tabular}

Note: EQLOw/EQHIGH serves as baseline. Standard errors are indicated in parentheses. Two-sided $p$-values: ${ }^{*} p<0.10,{ }^{* *} p<0.05,{ }^{* * *} p<0.01,{ }^{* * * *} p<0.001$. 
Table A3: $P$-Values of Six Predicted Differences in Labor Supply between Payment Schemes, for Men and Women

\begin{tabular}{|c|c|c|c|c|c|c|c|c|}
\hline \multicolumn{9}{|c|}{ Men } \\
\hline \multirow[b]{2}{*}{ Predicted Inequality } & \multicolumn{4}{|c|}{ Low-Wage Workers } & \multicolumn{4}{|c|}{ High-Wage Workers } \\
\hline & (1) & (2) & (3) & (4) & (5) & (6) & (7) & $(8)$ \\
\hline Technique & Dunn & Tobit & Dunn & Tobit & Dunn & Tobit & Dunn & Tobit \\
\hline BH Correction & No & No & Yes & Yes & No & No & Yes & Yes \\
\hline $\begin{array}{c}\text { EQLOW/EQHIGH }> \\
\text { UNEQFAIR }\end{array}$ & 0.002 & 0.016 & 0.012 & 0.098 & 0.818 & 0.783 & 0.818 & 0.979 \\
\hline $\begin{array}{l}\text { EQLOW/EQHIGH }> \\
\text { UNEQUNFAIR }\end{array}$ & 0.021 & 0.047 & 0.041 & 0.095 & 0.818 & 0.787 & 1.000 & 0.787 \\
\hline $\begin{array}{l}\text { EQLOW/EQHIGH }> \\
\text { UNEQDISCR }\end{array}$ & 0.018 & 0.035 & 0.055 & 0.106 & 0.111 & 0.382 & 0.222 & 0.764 \\
\hline $\begin{array}{l}\text { UNEQFAIR > } \\
\text { UNEQUNFAIR }\end{array}$ & 0.920 & 0.716 & 0.920 & 0.716 & 0.248 & 0.508 & 0.372 & 0.762 \\
\hline $\begin{array}{l}\text { UNEQFAIR > } \\
\text { UNEQDISCR }\end{array}$ & 0.912 & 0.630 & 1.000 & 0.787 & 0.065 & 0.122 & 0.196 & 0.731 \\
\hline $\begin{array}{l}\text { UNEQUNFAIR > } \\
\text { DISCRHANCE }\end{array}$ & 0.238 & 0.398 & 0.358 & 0.598 & 0.063 & 0.123 & 0.380 & 0.369 \\
\hline$N$ & 271 & 268 & 271 & 268 & 270 & 270 & 270 & 270 \\
\hline \multicolumn{9}{|c|}{ Women } \\
\hline & \multicolumn{4}{|c|}{ Low-Wage Workers } & \multicolumn{4}{|c|}{ High-Wage Workers } \\
\hline Predicted Inequality & $(1)$ & $(2)$ & $(3)$ & (4) & $(5)$ & (6) & (7) & $(8)$ \\
\hline Technique & Dunn & Tobit & Dunn & Tobit & Dunn & Tobit & Dunn & Tobit \\
\hline BH Correction & No & No & Yes & Yes & No & No & Yes & Yes \\
\hline $\begin{array}{l}\text { EQLOW/EQHIGH }> \\
\text { UNEQFAIR }\end{array}$ & 0.767 & 0.732 & 0.958 & 0.732 & 0.104 & 0.206 & 0.621 & 1.000 \\
\hline $\begin{array}{c}\text { EQLOW/EQHIGH > } \\
\text { UNEQUNFAIR }\end{array}$ & 0.768 & 0.548 & 0.768 & 0.685 & 0.139 & 0.206 & 0.418 & 0.618 \\
\hline $\begin{array}{c}\text { EQLOW/EQHIGH }> \\
\text { UNEQDISCR }\end{array}$ & 0.005 & 0.003 & 0.009 & 0.006 & 0.972 & 0.864 & 1.000 & 1.000 \\
\hline $\begin{array}{l}\text { UNEQFAIR > } \\
\text { UNEQUNFAIR }\end{array}$ & 0.751 & 0.305 & 1.126 & 0.457 & 0.801 & 0.517 & 1.000 & 1.000 \\
\hline $\begin{array}{l}\text { UNEQFAIR > } \\
\text { UNEQDISCR }\end{array}$ & 0.004 & 0.001 & 0.012 & 0.004 & 0.996 & 0.977 & 0.996 & 1.000 \\
\hline $\begin{array}{l}\text { UNEQUNFAIR > } \\
\text { UNEQDISCR }\end{array}$ & 0.003 & 0.001 & 0.018 & 0.004 & 0.994 & 0.981 & 1.000 & 0.981 \\
\hline$N$ & 268 & 265 & 268 & 265 & 273 & 272 & 273 & 272 \\
\hline
\end{tabular}

Note: One-sided $p$-values are presented, in the direction predicted. BH corrections account for multiple hypothesis testing. 
Table A4: $P$-Value of Test that Positive Discrimination of Women does not Affect their Labor Supply

\begin{tabular}{rcc}
\hline \hline & \multicolumn{2}{c}{ High-Wage Women } \\
\cline { 2 - 3 } Inequality & $(1)$ & $(2)$ \\
\hline Technique & Dunn & Tobit \\
\hline EQHIGH $\neq$ UNEQDISCR & 0.055 & 0.271 \\
UNEQUNFAIR $\neq$ UNEQDISCR & 0.012 & 0.038 \\
\hline$N$ & 273 & 272
\end{tabular}

Note: Two-sided $p$-values are presented. The Tobit estimates come from specification (5) of Table A2.

Table A5: Hurdle Model (Labor Supply on Payment Schemes), for Low-Wage Workers

\begin{tabular}{rc}
\hline \hline Scheme & Low-Wage Workers \\
\hline Extensive Margin & \\
UNEQFAIR & -4.417 \\
& $(5.927)$ \\
UNEQUNFAIR & -4.406 \\
& $(5.413)$ \\
UNEQDISCR & $-15.442^{* * *}$ \\
& $(5.715)$ \\
\hline Intensive Margin & \\
UNEQFAIR & $-0.516^{*}$ \\
& $(0.302)$ \\
UNEQUNFAIR & -0.304 \\
& $(0.316)$ \\
UNEQDisCR & $-0.773^{* *}$ \\
& $(0.307)$ \\
\hline Controls & Yes \\
\hline Prob $>F$ & 0.032 \\
Pseudo $R^{2}$ & 0.013 \\
$N$ & 533 \\
\hline
\end{tabular}

Note: EQLOw serves as baseline. Standard errors are in parentheses. Two-sided $p$ values: ${ }^{*} p<0.10,{ }^{* *} p<0.05,{ }^{* * *} p<0.01$, ${ }^{* * * *} p<0.001$. 
Table A6: P-Values of Six Predicted Differences in Labor Supply between Payment Schemes, Hurdle Model

\begin{tabular}{|c|c|c|c|c|}
\hline \multirow[b]{2}{*}{ Predicted Inequality } & \multicolumn{4}{|c|}{ Low-Wage Workers } \\
\hline & (1) & (2) & (3) & (4) \\
\hline Margin & \multicolumn{2}{|c|}{ Extensive } & \multicolumn{2}{|c|}{ Intensive } \\
\hline BH Correction & No & Yes & No & Yes \\
\hline $\begin{array}{c}\text { EQLOW/EQHIGH }> \\
\text { UNEQFAIR }\end{array}$ & 0.228 & 0.285 & 0.044 & 0.087 \\
\hline $\begin{array}{c}\text { EQLOW/EQHIGH > } \\
\text { UNEQUNFAIR }\end{array}$ & 0.208 & 0.312 & 0.168 & 0.210 \\
\hline $\begin{array}{l}\text { EQLOW/EQHIGH }> \\
\text { UNEQDISCR }\end{array}$ & 0.003 & 0.021 & 0.006 & 0.035 \\
\hline $\begin{array}{l}\text { UNEQFAIR > } \\
\text { UNEQUNFAIR }\end{array}$ & 0.501 & 0.501 & 0.787 & 0.787 \\
\hline $\begin{array}{l}\text { UNEQFAIR > } \\
\text { UNEQDISCR }\end{array}$ & 0.039 & 0.078 & 0.138 & 0.206 \\
\hline $\begin{array}{l}\text { UNEQUNFAIR > } \\
\text { UNEQDISCR }\end{array}$ & 0.026 & 0.079 & 0.029 & 0.086 \\
\hline$N$ & 533 & 533 & 533 & 533 \\
\hline
\end{tabular}

Note: One-sided $p$-values are presented, in the direction predicted. $\mathrm{BH}$ corrections account for multiple hypothesis testing.

Table A7: Tobit Regression of Labor Supply on Payment Schemes, for Young (age $\leq 36$ ) and Old (age $>36$ )

\begin{tabular}{rccccc}
\hline \hline & \multicolumn{2}{c}{ Low-Wage Workers } & & \multicolumn{2}{c}{ High-Wage Workers } \\
\cline { 2 - 3 } \cline { 5 - 6 } Scheme & Young & Old & & Young & Old \\
& $(1)$ & $(2)$ & & $(3)$ & $(4)$ \\
\hline UNEQFAIR & -5.633 & -4.065 & & -9.100 & 5.953 \\
& $(6.245)$ & $(6.183)$ & & $(7.093)$ & $(6.122)$ \\
UNEQUNFAIR & $-10.527^{*}$ & 0.962 & & -5.550 & 1.650 \\
& $(6.099)$ & $(5.712)$ & & $(6.463)$ & $(6.260)$ \\
UNEQDISCR & $-18.440^{* * *}$ & $-9.274^{*}$ & & -0.442 & 3.300 \\
& $(6.241)$ & $(5.360)$ & & $(6.158)$ & $(5.940)$ \\
\hline Controls & Yes & Yes & & Yes & Yes \\
\hline Prob $>F$ & 0.034 & 0.088 & & 0.000 & 0.625 \\
Pseudo $R^{2}$ & 0.013 & 0.014 & & 0.011 & 0.007 \\
$N$ & 260 & 273 & & 290 & 252 \\
\hline
\end{tabular}

Note: Median age is 36 in the sample. EQLow/EQHIGH serves as baseline. Standard errors are in parentheses. Two-sided $p$-values: ${ }^{*} p<0.10$, ${ }^{* *} p<0.05,{ }^{* * *} p<0.01,{ }^{* * * *} p<0.001$. 
Table A8: $P$-Values of Six Predicted Differences in Labor Supply between Payment Schemes, for Young $($ age $\leq 36)$ and Old (age $>36)$

\begin{tabular}{|c|c|c|c|c|c|c|c|c|}
\hline \multicolumn{9}{|c|}{ Young } \\
\hline \multirow[b]{2}{*}{ Predicted Inequality } & \multicolumn{4}{|c|}{ Low-Wage Workers } & \multicolumn{4}{|c|}{ High-Wage Workers } \\
\hline & (1) & $(2)$ & (3) & (4) & (5) & (6) & $(7)$ & $(8)$ \\
\hline Technique & Dunn & Tobit & Dunn & Tobit & Dunn & Tobit & Dunn & Tobit \\
\hline BH Correction & No & No & Yes & Yes & No & No & Yes & Yes \\
\hline $\begin{array}{c}\text { EQLOW/EQHIGH }> \\
\text { UNEQFAIR }\end{array}$ & 0.086 & 0.184 & 0.108 & 0.230 & 0.054 & 0.100 & 0.321 & 0.602 \\
\hline $\begin{array}{l}\text { EQLOW/EQHIGH > } \\
\text { UNEQUNFAIR }\end{array}$ & 0.047 & 0.043 & 0.094 & 0.086 & 0.106 & 0.196 & 0.318 & 0.587 \\
\hline $\begin{array}{l}\text { EQLOW/EQHIGH > } \\
\text { UNEQDISCR }\end{array}$ & 0.003 & 0.002 & 0.018 & 0.010 & 0.751 & 0.471 & 1.000 & 0.943 \\
\hline $\begin{array}{l}\text { UNEQFAIR > } \\
\text { UNEQUNFAIR }\end{array}$ & 0.187 & 0.207 & 0.187 & 0.207 & 0.851 & 0.712 & 1.000 & 1.000 \\
\hline $\begin{array}{l}\text { UNEQFAIR > } \\
\text { UNEQDISCR }\end{array}$ & 0.036 & 0.017 & 0.108 & 0.052 & 0.952 & 0.918 & 0.952 & 0.918 \\
\hline $\begin{array}{l}\text { UNEQUNFAIR > } \\
\text { DISCRHANCE }\end{array}$ & 0.058 & 0.088 & 0.087 & 0.132 & 0.901 & 0.823 & 1.000 & 1.000 \\
\hline$N$ & 263 & 260 & 263 & 260 & 291 & 290 & 291 & 290 \\
\hline \multicolumn{9}{|c|}{ Old } \\
\hline & \multicolumn{4}{|c|}{ Low-Wage Workers } & \multicolumn{4}{|c|}{ High-Wage Workers } \\
\hline Predicted Inequality & (1) & (2) & (3) & (4) & (5) & (6) & (7) & $(8)$ \\
\hline $\begin{array}{r}\text { Technique } \\
\text { BH Correction }\end{array}$ & $\begin{array}{c}\text { Dunn } \\
\text { No }\end{array}$ & $\begin{array}{l}\text { Tobit } \\
\text { No }\end{array}$ & $\begin{array}{c}\text { Dunn } \\
\text { Yes }\end{array}$ & $\begin{array}{l}\text { Tobit } \\
\text { Yes }\end{array}$ & $\begin{array}{c}\text { Dunn } \\
\text { No }\end{array}$ & $\begin{array}{l}\text { Tobit } \\
\text { No }\end{array}$ & $\begin{array}{c}\text { Dunn } \\
\text { Yes }\end{array}$ & $\begin{array}{l}\text { Tobit } \\
\text { Yes }\end{array}$ \\
\hline $\begin{array}{l}\text { EQLOW/EQHIGH }> \\
\text { UNEQFAIR }\end{array}$ & 0.032 & 0.256 & 0.096 & 0.384 & 0.877 & 0.834 & 0.877 & 0.834 \\
\hline $\begin{array}{l}\text { EQLOW/EQHIGH }> \\
\text { UNEQUNFAIR }\end{array}$ & 0.191 & 0.567 & 0.287 & 0.709 & 0.791 & 0.604 & 1.000 & 1.000 \\
\hline $\begin{array}{l}\text { EQLOW/EQHIGH > } \\
\text { UNEQDISCR }\end{array}$ & 0.032 & 0.042 & 0.190 & 0.127 & 0.863 & 0.711 & 1.000 & 0.888 \\
\hline $\begin{array}{l}\text { UNEQFAIR > } \\
\text { UNEQUNFAIR }\end{array}$ & 0.950 & 0.792 & 0.950 & 0.792 & 0.162 & 0.244 & 0.974 & 1.000 \\
\hline $\begin{array}{l}\text { UNEQFAIR > } \\
\text { UNEQDISCR }\end{array}$ & 0.755 & 0.186 & 0.944 & 0.371 & 0.229 & 0.322 & 0.687 & 0.966 \\
\hline $\begin{array}{l}\text { UNEQUNFAIR > } \\
\text { UNEQDISCR }\end{array}$ & 0.049 & 0.023 & 0.099 & 0.140 & 0.821 & 0.607 & 1.000 & 0.911 \\
\hline$N$ & 276 & 273 & 276 & 273 & 252 & 252 & 252 & 252 \\
\hline
\end{tabular}

Note: One-sided $p$-values are presented, in the direction predicted. BH corrections account for multiple hypothesis testing. 
Table A9: Tobit Regression of Labor Supply on Payment Schemes, for Employed Full Time and Not Employed Full Time

\begin{tabular}{rccccc}
\hline \hline & \multicolumn{2}{c}{ Low-Wage Workers } & & \multicolumn{2}{c}{ High-Wage Workers } \\
\cline { 2 - 3 } \cline { 5 - 6 } Scheme & Full-Time & Not Full-Time & & Full-Time & Not Full-Time \\
& $(1)$ & $(2)$ & & $(3)$ & $(4)$ \\
\hline UNEQFAIR & -7.091 & 0.891 & & -1.010 & -3.379 \\
& $(6.546)$ & $(5.955)$ & & $(6.384)$ & $(6.724)$ \\
UNEQUNFAIR & -7.809 & -0.410 & & 2.169 & -5.549 \\
& $(6.109)$ & $(5.661)$ & & $(6.374)$ & $(6.327)$ \\
UNEQDISCR & $-10.922^{*}$ & $-15.172^{* * *}$ & & 5.921 & -5.965 \\
& $(6.074)$ & $(5.578)$ & & $(5.872)$ & $(6.239)$ \\
\hline Controls & Yes & Yes & & Yes & Yes \\
\hline Prob $>F$ & 0.301 & 0.002 & & 0.003 & $<0.001$ \\
Pseudo $R^{2}$ & 0.009 & 0.017 & & 0.004 & 0.017 \\
$N$ & 254 & 279 & & 296 & 246 \\
\hline
\end{tabular}

Note: Workers who are full-time employed account for $51 \%$ of the sample. Those who are not full-time employed are: part-time employed (20\%), unemployed (6\%), not in a paid job (18\%) or other (5\%). EQLOW/EQHIGH serves as baseline. Standard errors are in parentheses. Two-sided $p$-values: ${ }^{*} p<0.10,{ }^{* *} p<0.05,{ }^{* * *} p<0.01$, ${ }^{* * * *} p<0.001$. 
Table A10: $P$-Values of Six Predicted Differences in Labor Supply between Payment Schemes, for Employed Full Time and Not Employed Full Time Employed Full Time

\begin{tabular}{|c|c|c|c|c|c|c|c|c|}
\hline \multirow[b]{2}{*}{ Predicted Inequality } & \multicolumn{4}{|c|}{ Low-Wage Workers } & \multicolumn{4}{|c|}{ High-Wage Workers } \\
\hline & (1) & (2) & (3) & (4) & (5) & (6) & (7) & $(8)$ \\
\hline Technique & Dunn & Tobit & Dunn & Tobit & Dunn & Tobit & Dunn & Tobit \\
\hline BH Correction & No & No & Yes & Yes & No & No & Yes & Yes \\
\hline $\begin{array}{l}\text { EQLOW/EQHIGH }> \\
\text { UNEQFAIR }\end{array}$ & 0.033 & 0.140 & 0.066 & 0.280 & 0.183 & 0.437 & 1.000 & 1.000 \\
\hline $\begin{array}{c}\text { EQLOW/EQHIGH > } \\
\text { UNEQUNFAIR }\end{array}$ & 0.029 & 0.101 & 0.086 & 0.304 & 0.752 & 0.633 & 1.000 & 1.000 \\
\hline $\begin{array}{l}\text { EQLOW/EQHIGH }> \\
\text { UNEQDISCR }\end{array}$ & 0.016 & 0.037 & 0.094 & 0.220 & 0.944 & 0.843 & 1.000 & 1.000 \\
\hline $\begin{array}{l}\text { UNEQFAIR > } \\
\text { UNEQUNFAIR }\end{array}$ & 0.244 & 0.455 & 0.244 & 0.455 & 0.821 & 0.694 & 1.000 & 1.000 \\
\hline $\begin{array}{l}\text { UNEQFAIR > } \\
\text { UNEQDISCR }\end{array}$ & 0.183 & 0.256 & 0.275 & 0.384 & 0.973 & 0.889 & 0.973 & 0.889 \\
\hline $\begin{array}{l}\text { UNEQUNFAIR > } \\
\text { UNEQDISCR }\end{array}$ & 0.187 & 0.280 & 0.234 & 0.349 & 0.947 & 0.749 & 1.000 & 1.000 \\
\hline$N$ & 254 & 254 & 254 & 254 & 296 & 296 & 296 & 296 \\
\hline \multicolumn{9}{|c|}{ Not Employed Full Time } \\
\hline & \multicolumn{4}{|c|}{ Low-Wage Workers } & \multicolumn{4}{|c|}{ High-Wage Workers } \\
\hline Predicted Inequality & $(1)$ & $(2)$ & (3) & $(4)$ & $(5)$ & (6) & (7) & $(8)$ \\
\hline Technique & Dunn & Tobit & Dunn & Tobit & Dunn & Tobit & Dunn & Tobit \\
\hline BH Correction & No & No & Yes & Yes & No & No & Yes & Yes \\
\hline $\begin{array}{l}\text { EQLOW/EQHIGH }> \\
\text { UNEQFAIR }\end{array}$ & 0.089 & 0.559 & 0.133 & 0.559 & 0.249 & 0.308 & 0.249 & 0.616 \\
\hline $\begin{array}{c}\text { EQLOW/EQHIGH > } \\
\text { UNEQUNFAIR }\end{array}$ & 0.216 & 0.471 & 0.270 & 0.589 & 0.221 & 0.191 & 0.286 & 0.572 \\
\hline $\begin{array}{l}\text { EQLOW/EQHIGH }> \\
\text { UNEQDISCR }\end{array}$ & 0.004 & 0.004 & 0.023 & 0.021 & 0.165 & 0.170 & 0.990 & 1.000 \\
\hline $\begin{array}{l}\text { UNEQFAIR > } \\
\text { UNEQUNFAIR }\end{array}$ & 0.889 & 0.415 & 0.889 & 0.622 & 0.222 & 0.361 & 0.278 & 0.452 \\
\hline $\begin{array}{l}\text { UNEQFAIR > } \\
\text { UNEQDISCR }\end{array}$ & 0.041 & 0.005 & 0.082 & 0.009 & 0.167 & 0.338 & 0.502 & 0.507 \\
\hline $\begin{array}{l}\text { UNEQUNFAIR }> \\
\text { DISCRHANCE }\end{array}$ & 0.006 & 0.004 & 0.018 & 0.011 & 0.190 & 0.471 & 0.380 & 0.471 \\
\hline$N$ & 279 & 279 & 279 & 279 & 246 & 246 & 246 & 246 \\
\hline
\end{tabular}

Note: One-sided $p$-values are presented, in the direction predicted. BH corrections account for multiple hypothesis testing. 
Table A11: Tobit Regression of Time Spent in the Experiment on Payment Schemes

\begin{tabular}{rccc}
\hline \hline & Low-Wage Workers & & High-Wage Workers \\
\cline { 2 - 2 } Scheme & $(1)$ & & $(2)$ \\
\hline UNEQFAIR & -1.478 & & -0.729 \\
& $(1.935)$ & & $(2.002)$ \\
UNEQUNFAIR & -0.720 & & -0.062 \\
& $(1.803)$ & & $(1.946)$ \\
UNEQDISCR & $-4.621^{* * *}$ & & 2.060 \\
& $(1.760)$ & & $(1.923)$ \\
\hline Controls & Yes & Yes \\
\hline Prob $>F$ & 0.002 & & 0.004 \\
Pseudo $R^{2}$ & 0.009 & & 0.008 \\
$N$ & 533 &
\end{tabular}

Note: Time spent in the experiment is measured in minutes. Mean times are $22.65(\mathrm{SD}=14.96)$ minutes for low-wage workers, and $28.19(\mathrm{SD}=$ 16.02) minutes for high-wage workers. Note that our time measure is not necessarily time worked since it starts when workers begin reading the instructions and ends when they quit the experiment or at 65 minutes if they have not quit by then. Moreover, this measure does not account for the breaks that workers can take. Therefore, it is most likely not an appropriate measure of labor supply. EQLOW/EQHIGH serves as baseline. Standard errors are in parentheses. Two-sided $p$-values: ${ }^{*} p<$ $0.10,{ }^{* *} p<0.05,{ }^{* * *} p<0.01,{ }^{* * * *} p<0.001$.

Table A12: P-Values of Six Predicted Differences in Time Spent in the Experiment between Payment Schemes

\begin{tabular}{|c|c|c|c|c|c|c|c|c|}
\hline \multirow[b]{2}{*}{ Predicted Inequality } & \multicolumn{4}{|c|}{ Low-Wage Workers } & \multicolumn{4}{|c|}{ High-Wage Workers } \\
\hline & (1) & (2) & (3) & (4) & (5) & (6) & (7) & (8) \\
\hline Technique & Dunn & Tobit & Dunn & Tobit & Dunn & Tobit & Dunn & Tobit \\
\hline BH Correction & No & Yes & No & Yes & No & Yes & No & Yes \\
\hline $\begin{array}{c}\text { EQLOW/EQHIGH > } \\
\text { UNEOFAIR }\end{array}$ & 0.028 & 0.223 & 0.057 & 0.334 & 0.148 & 0.358 & 0.889 & 1.000 \\
\hline $\begin{array}{c}\text { EQLOW/EQHIGH }> \\
\text { UNEQUNFAIR }\end{array}$ & 0.180 & 0.345 & 0.225 & 0.431 & 0.247 & 0.487 & 0.741 & 1.000 \\
\hline $\begin{array}{l}\text { EQLOW/EQHIGH }> \\
\text { UNEQDISCR }\end{array}$ & 0.006 & 0.004 & 0.037 & 0.027 & 0.921 & 0.858 & 1.000 & 1.000 \\
\hline $\begin{array}{l}\text { UNEQFAIR > } \\
\text { UNEQUNFAIR }\end{array}$ & 0.949 & 0.657 & 0.949 & 0.657 & 0.852 & 0.639 & 1.000 & 1.000 \\
\hline $\begin{array}{l}\text { UNEQFAIR > } \\
\text { UNEQDISCR }\end{array}$ & 0.137 & 0.042 & 0.205 & 0.083 & 0.907 & 0.929 & 0.970 & 0.929 \\
\hline $\begin{array}{l}\text { UNEQUNFAIR > } \\
\text { UNEQDISCR }\end{array}$ & 0.013 & 0.010 & 0.039 & 0.029 & 0.926 & 0.879 & 1.000 & 1.000 \\
\hline$N$ & 539 & 533 & 539 & 533 & 543 & 542 & 543 & 542 \\
\hline
\end{tabular}

Note: One-sided $p$-values are presented, in the direction predicted. BH corrections account for multiple hypothesis testing. 
Table A13: Labor Supply per Payment Scheme, for Workers not Beating the Odds and Workers Beating the Odds

\begin{tabular}{rccccc}
\hline \hline Low-Wage Workers & Mean & SD & Min. & Max. & $N$ \\
\hline Workers not Beating the Odds & & & & & \\
EQLOW & 43.20 & 27.63 & .04 & .16 & 128 \\
UNEQFAIR & 37.44 & 29.16 & .06 & .17 & 125 \\
UNEQUNFAIR & 39.22 & 27.76 & .04 & .15 & 143 \\
UNEQDISCR & 33.62 & 26.41 & .08 & .11 & 143 \\
Workers Beating the Odds & & & & & \\
UNEQUNFAIR(BEATODDS) & 37.98 & 27.58 & .02 & .16 & 50 \\
UnEQDISCR(BEATODDS) & 38.15 & 32.10 & .04 & .24 & 46 \\
\hline High-Wage Workers & Mean & SD & Min. & Max. & $N$ \\
\hline Workers not Beating the Odds & & & & & \\
EQHIGH & 44.03 & 28.93 & .04 & .20 & 128 \\
UNEQFAIR & 43.23 & 29.64 & .03 & .20 & 127 \\
UNEQUNFAIR & 43.50 & 28.85 & .02 & .20 & 143 \\
UNEQDISCR & 45.74 & 26.72 & .02 & .16 & 145 \\
Workers Beating the Odds & & & & & \\
UNEQUNFAIR(BEATODDS) & 42.55 & 28.34 & .02 & .17 & 47 \\
UNEQDISCR(BEATODDS) & 40.72 & 27.79 & .02 & .15 & 46 \\
\hline
\end{tabular}

Note: Labor supply is measured by the number of lines completed and ranges from 0 to 85 . Min. and Max. indicate the percentage of workers completing the minimum and maximum number of lines. Low-wage workers beating the odds had high chances, and high-wage workers beating the odds had low chances.

Table A14: $P$-Values of Tests on Difference in Labor Supply between Payment Schemes, for Workers Beating the Odds

\begin{tabular}{|c|c|c|c|c|}
\hline \multirow[b]{2}{*}{ Predicted Inequality } & \multicolumn{2}{|c|}{ Low-Wage Workers } & \multicolumn{2}{|c|}{ High-Wage Workers } \\
\hline & (1) & (2) & (3) & (4) \\
\hline Technique & Dunn & Tobit & Dunn & Tobit \\
\hline $\begin{array}{l}\text { UNEQFAIR > } \\
\text { UNEQUNFAIR(BEATODDS) }\end{array}$ & 0.181 & 0.316 & 0.241 & 0.454 \\
\hline $\begin{array}{l}\text { UNEQUNFAIR(BEATODDS) > } \\
\text { UNEQDISCR(BEATODDS) }\end{array}$ & 0.811 & 0.658 & 0.192 & 0.279 \\
\hline$N$ & 221 & 219 & 220 & 219 \\
\hline
\end{tabular}

Notes: One-sided $p$-values are presented, in the direction predicted by the model. 


\section{B. Instructions of the Experiment}

\section{Invitation Email}

[Notes: Potential participants see the time limit that they have to complete the experiment]

We would like to invite you to participate in an online economic experiment about decision making. You will be paid a reward of 0.70 for about 5 minutes of participation. Thereafter, as will be explained in the instructions, you can earn more money with the decisions you make by participating in this experiment for a longer time.

IMPORTANT: All information provided will be collected and stored ANONYMOUSLY.

$* * * * * * * * * * * * * * * * * * * * *$

You receive this invitation because you are registered at Prolific. Please consult the Prolific website in case you want your data to be removed from the platform. 


\section{Instructions}

[Notes: Participants are provided with a countdown from 65 to 0 minutes.]

\section{Instructions}

Welcome to this economic experiment,

You can earn a considerable amount of money with the decisions you make. Please read these instructions carefully. Importantly, unlike experiments in some other social sciences, economic experiments employ a strict non-deception policy. This means that all information you receive is truthful.

The only way to leave this economic experiment and be paid is to click on the button "Leave" and go to the next page. Once you do this, you will see a message that the experiment is now over and that you can close your browser page. You will not be paid if you leave at any moment by closing your browser window without clicking on the button "Leave" and going to the next page that tells you that the experiment is over.

This economic experiment consists of a Practice Part, where you cannot yet earn money, followed by a Task Part where you can earn money. The Practice Part consists of these Instructions, some comprehension questions, and a practice exercise. It is important that you answer the comprehension questions correctly by yourself. Please do not consult other people when answering these questions. In case you do not answer a question correctly, you will have two more chances to correct your answer. If you do not answer all questions correctly after these two additional chances, you will not be able to participate in the Task Part and the experiment ends for you. In that case you will be paid $£ 0.45$. When you have answered all comprehension questions correctly you can participate in the Task Part. In the Task Part, you can earn money by working on a task. You can stop working on the task whenever you prefer.

Recall, that to leave this economic experiment and to be paid you need to click on the "Leave " button and go to the next page. Once you have done this, you will see a message that the experiment is over for you and that you can close your browser page. You will not be paid if you leave the experiment without following the described procedure.

Note that you cannot leave the experiment and be paid before you finish the Practice Part 
(which lasts about 5 minutes). Thereafter you can leave the experiment at any time.

After you leave the experiment using the "Leave button, the money you have earned will be paid to you through Prolific.

\section{Task Part}

In the Task Part of this experiment, you can earn money by working on a task. You can decide how much of the task you want to complete. The task is to enter preset lines of random numbers and/or letters on your computer. You will receive a payment for each line you copy correctly. Nobody else than yourself will derive any earnings from your work, including the experimenters. The lines of numbers and/or letters you enter have no further use for anyone.

You will see one line at the time. Once you have entered a line correctly, you can go to the next page to see the next line. Each time you see a new line, you can decide whether you would like to type this line or leave the experiment.

In case you make a mistake when entering the line, the software will tell you so. You will need to correct this mistake before you can proceed to the next line.

The length of the sequences of random numbers and/or letters will increase as you complete more lines. That is, lines will be relatively short at the beginning but get longer over time.

You will be informed of your payment per line at the beginning of the Task Part.

In the Task Part you may also receive anonymous payment information regarding another participant.

\section{Leave the Experiment}

You can stop entering lines at any moment. Note, however, that the only way to stop and to be paid is to click on the "Leave" button and then go to the next page. You will then see a message that the experiment is over for you, that you need to click on a Prolific link to validate your participation, and that you can then close your browser window.

You will see the Leave button whenever you are presented a new line. If you decide to leave, you will not be able to start working again. That is, once you leave the experiment you cannot go back. 


\section{Payment}

When you leave the experiment according to the described procedure you will receive a payment per line you entered correctly. You will be informed about the amount of the payment per line when you see the first line to be entered. In addition, you will also receive a fixed amount of $£ \mathbf{0 . 7 0}$, irrespective of the number of lines entered.

\section{Decision}

The decision you make in this economic experiment is to choose how much of the task you want to complete. You are the only one deciding how much you work. Your decision only affects your own earnings.

\section{Practice Part}

In the Practice Part, we ask you to correctly answer a number of comprehension questions. It is important that you answer these comprehension questions by yourself. For each question you will have three chances. If you do not correctly answer all comprehension questions you will not be able to participate in the Task Part. In this case the experiment will end for you and you will be paid 0.45 .

After having correctly answered all comprehension questions, you will enter two practice lines to make you familiar with the task. Neither can you earn payments per line with these practice lines, nor will these practice lines affect the Task Part in any way.

This is the end of the instructions.

I confirm that I have read the instructions carefully and I am ready to start the Practice Part. I will not be able to go back to the instructions once I go to the next page. 